\title{
Infections in Allogeneic Stem Cell Transplantation
}

\author{
Marcus R. Pereira, Stephanie M. Pouch, and Brian Scully
}

\section{Introduction}

\begin{abstract}
Allogeneic hematopoietic stem cell transplantation (alloHSCT) has become a widely used modality of therapy for a variety of malignant and nonmalignant diseases. While many advances have been made in the field, infection remains one of the most severe and frequently encountered complications of HSCT. In this chapter we review the defects in host defenses and important risk factors predisposing allo-HSCT recipients to infection, the major categories of infection and their time courses following transplantation, and preventive strategies.
\end{abstract}

\section{Risk Factors for Infection Following Allo-HSCT}

The severity of defects in host defenses and the subsequent risk of infection are influenced by a complex interaction between several factors. Particularly salient are (1) the underlying illness of the patient, (2) the conditioning regimen, (3) the graft and the closeness of the match, (4) the type of transplant, and (5) the presence of graft-versus-host disease (GVHD). Immediate local and remote epidemiological factors are also important. The timing of impaired host defenses and infectious risk in allo-HSCT recipients are outlined in Fig. 11.1.
M. R. Pereira $(\bowtie) \cdot$ B. Scully

Department of Medicine - Infectious Diseases, Columbia

University Medical Center, New York, NY, USA

e-mail:mp2323@cumc.columbia.edu; bs4@cumc.columbia.edu

S. M. Pouch

Division of Infectious Diseases, Emory University,

Atlanta, GA, USA

e-mail: spouch@emory.edu

\section{Underlying Host Disease}

Infection risk is very much impacted by the disease for which the patient is being transplanted and also by the presence of preceding infections. Acute leukemia, for example, predisposes to neutropenia and other defects of innate immunity. Profound neutropenia $\left(<500\right.$ cells $\left./ \mathrm{mm}^{3}\right)$ of greater than 10-day duration is considered a strong risk factor for bacterial and invasive fungal infection [1]. In addition to neutropenia, other factors that increase risk for invasive aspergillosis include advanced or refractory acute myelogenous leukemia, high-risk myelodysplastic syndrome, chronic neutropenia prior to chemotherapy, iron overload secondary to repeated peripheral blood transfusions, and prior fungal infection [2-6]. Further, antileukemic agents have been shown to diminish antibody response to primary antigens, thereby increasing susceptibility to bacterial pathogens even in the absence of neutropenia [7]. Other underlying diseases such as primary immunodeficiency, for example, may predispose to progression or reactivation of antecedent infections, and individuals with myelodysplastic syndrome who are neutropenic at the time of transplant are at an increased risk of infection and mortality. In addition to innate immune defects, increasing age, waning cellular immunity, organ dysfunction, fragile skin, and prior antibiotic exposure may all contribute to the progression of preexisting infection, including aspergillosis, as well as to the risk for new infections during the posttransplant period [8-11].

The presence of infection immediately preceding alloHSCT also impacts infectious risk during the posttransplant period. In individuals scheduled to undergo allo-HSCT, active infections should be treated prior to transplantation whenever possible. The timing of alloHSCT following the initiation of antibiotics for active infection should be made on a case by case basis by an experienced practitioner. 


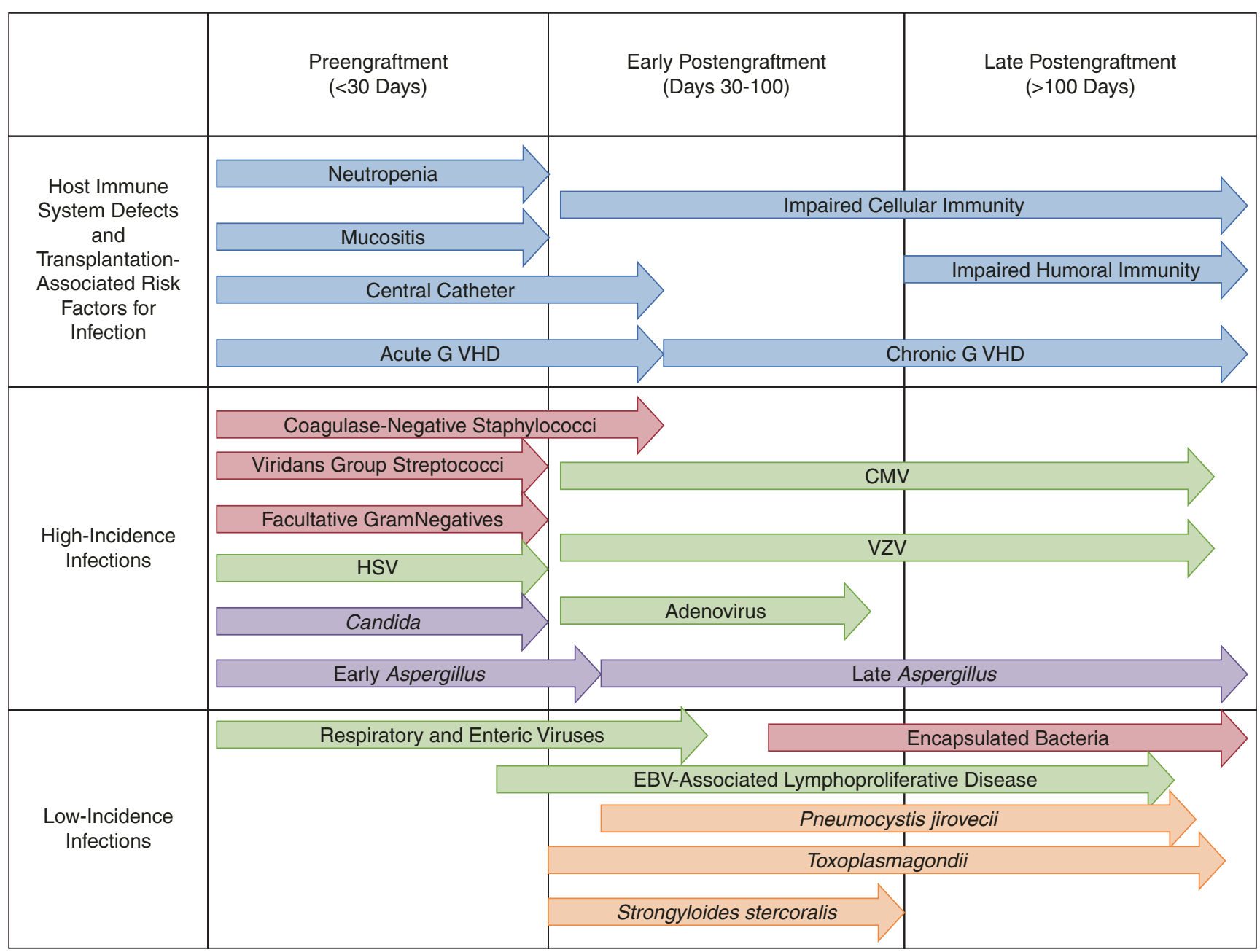

Fig. 11.1 Timeline of host immune defects and infections in AlloHSCT recipients. Predictable opportunistic infections encountered following allo-HSCT. Immune defects and transplant-associated risk factors are shaded in blue, bacterial infections in pink, viral infections in green, fungal infections in purple, and parasitic infections in orange

\section{The Graft}

The closeness of the human leukocyte antigen (HLA) match dictates the likelihood and severity of GVHD as well as the intensity of the immunosuppressive regimen. The various degrees of match include the following: the donor may be an HLA-matched sibling or twin, HLA-matched but unrelated, haploidentical such that donor and recipient share one complete haplotype, or partially matched. The latter two categories often necessitate more intense immunosuppressive regimens to prevent GVHD.

The source of the stem cells also impacts the risk of infection. Bone marrow transplant recipients have more prolonged periods of neutropenia and a higher risk for early infection, but lower risk of GVHD than peripheral stem cells mobilized by granulocyte colony-stimulating factor $[13,14]$. Cord blood cells, in contrast, are typically obtained from unrelated donors and confer a much lower 
stem cell dose than in the other transplants. Cord blood stem cell transplant recipients have delayed engraftment, such that neutropenia may extend for 6 weeks or longer and T-cell immune dysfunction may persist for months to years [15].

\section{Graft-Versus-Host Disease}

GVHD occurs when donor T-cells attack the recipient's tissues as a consequence of either T-cell ablation of the graft prior to transplant or by the administration of immunosuppressive drugs after transplantation. When unmanipulated bone marrow or peripheral stem cells are used, 24-300 $\times 10^{6} \%$ $\mathrm{kg}$ CD3 cells are administered. Ex vivo pretreatment of the graft may produce up to a 3-log reduction in cells transplanted and decrease the potential risk and severity of GVHD. However, there is a resultant prolonged T-cell immunodeficiency, and the patient must then walk an immunological-infection tightrope for many months. If an untreated graft is transplanted, then any one of a variety of immunosuppressive regimens may be given. Examples are sirolimus and a calcineurin inhibitor, such as tacrolimus. It appears that these regimens pose a lower infection risk than pretransplant T-cell ablation [16]. Sirolimus therapy has also been associated with a reduced risk of cytomegalovirus (CMV) infection [17, 18].

GVHD is classified as acute when the onset is prior to posttransplant day 100 and chronic when the onset is after day 100. Acute disease may persist into the chronic period, in which case it is termed progressive. While GVHD may respond to treatment and go into remission, it may also reactivate at a later date.

Acute disease, characterized by secretory diarrhea, hepatitis, and skin rash, is categorized according to severity with grades 3 and 4 posing an increased risk of mortality. Corticosteroids are the mainstay of therapy. The intense immunosuppression associated with the condition itself and enhanced by its treatment, combined with disrupted barrier defenses, especially in the intestine, place patients at great risk of infection. CMV infection is common as are other viral, bacterial, and fungal infections such as aspergillosis [19].

In chronic GVHD, humoral defects and functional hyposplenism markedly suppress cellular immunity. Severe pneumococcal, disseminated fungal, and CMV infections are frequently seen in this context [20, 21]. Infections are even more problematic when steroid-refractory disease necessitates the use of potent immunosuppressive regimens such as cyclophosphamide, alemtuzumab, or anti-thymocyte globulin. In this situation, human herpesvirus-6 (HHV6), adenovirus, disseminated fungal and nocardial infections, as well as posttransplant lymphoproliferative disease (PTLD) may occur [22].

\section{Timing of Opportunistic Infections in Allo-HSCT Recipients}

Three periods of immunodeficiency occur following hematopoietic stem cell transplantation: pre-engraftment (days $0-30$ ), early post-engraftment (days $30-100$ ), and late postengraftment (until day 100). The immune suppression that takes place during each of the periods conveys a particular risk for infection and drives the use of standard prophylaxis following transplantation (Figs. 11.1) [23, 24].

\section{Pre-engraftment}

The pre-engraftment period is associated with three major risk factors for infection: (1) prolonged neutropenia, (2) disruption of the mucosal barrier related to preparative chemotherapeutic regimens, and (3) the presence and frequent utilization of central venous access $[24,25]$. The combined effect of neutropenia and mucositis contributes to high risk of reactivation of HSV in seropositive patients, prompting standard use of acyclovir during this period [26, 27]. These factors also predispose to candidemia and early-onset aspergillosis [24]. While prophylactic antifungals are used in the pre-engraftment period, fluconazole prophylaxis has been linked to an increased risk of non-albicans candidal infections, particularly due to $C$. glabrata and C. krusei [28-30]. Voriconazole prophylaxis has also been associated with an increased risk of zygomycosis in this setting [31-34]. Additionally, mechanical disruption of the skin and the use of prophylactic antibiotics targeted toward gut flora increase the risk for bloodstream infections with Gram-positive flora, particularly viridians group streptococci and coagulase-negative staphylococci $[25,35]$.

\section{Early Post-engraftment}

The early post-engraftment period extends from the time of neutrophil recovery (approximately day 30 posttransplantation) until day 100 and is notable for B- and T-lymphocyte dysfunction. In the setting of allo-HSCT recipients, the impact of this immunodeficiency is further mediated by GVHD and CMV infection, as well as their treatments. Such cell-mediated immune dysfunction contributes to increased risk for viral infections, including CMV, adenovirus, varicella zoster virus (VZV), and Epstein-Barr virus (EBV)-related PTLD, as well as late-onset aspergillosis and Pneumocystis jirovecii [24].

\section{Late Post-engraftment}

The late post-engraftment period extends from day 100 until normal immune function is regained. While immune func- 
tion generally returns within 18-36 months of transplant, the duration of the late post-engraftment period may be extended in allo-HSCT recipients owing to chronic GVHD and its management. During this time, ongoing humeral and cellmediated immune dysfunction contributes to the risk for infections with VZV, CMV, late-onset aspergillosis, and infections with encapsulated bacteria [24, 36, 37].

\section{Bacterial Infections}

The microbiology of bacterial infections in allo-HSCT patients has evolved over time. In the past decade or so, it has been greatly influenced by the widespread use of fluoroquinolone prophylaxis, the increased prevalence of Clostridium difficile infection, and the evolution of conditioning regimens. Once transplanted, patients are at increased risk for bacterial infections for the remainder of their lifetime.

\section{Infection During the Pre-engraftment Period}

During the pre-engraftment period, bacteremia occurs in up to $20 \%$ of patients [38]. Table 11.1 lists some common infecting pathogens, their particular risks, and their clinical manifestations. The main sources for bacteremia are the oral or gastrointestinal mucositis, the respiratory tract, and the presence of central venous catheters. Infecting organisms are commonly Gram-positive cocci such as Streptococcus viridans and enterococci or a variety of fermenting and nonfermenting Gram-negative rods. Enterococci are increasingly resistant to vancomycin, and these strains have been associated with a worse prognosis than vancomycin-sensitive strains [39]. Some recent studies also report an increase in infections due to multidrug resistant (MDR) Gram-negative rods such as Pseudomonas aeruginosa and carbapenemaseproducing Klebsiella pneumoniae [40-43]. The isolation of such resistant bacteria has been associated with the use of fluoroquinolone prophylaxis and third-generation cephalosporins in several reports. These infections carry a high mortality and often relapse.

Gastrointestinal infections are prominent during this period. Necrotizing enterocolitis and typhlitis may occur in any severely neutropenic patient and can serve as a source of bacteremia and sepsis. Clostridium difficile colitis is very common, occurring in about $12 \%$ of allogeneic transplant patients versus $9 \%$ of autologous patients during the preengraftment period [44-46]. Extensive antibiotic exposures, mucosal damage from intense chemotherapy, and multiple prior hospitalizations are all contributory [47]. Clostridium difficile has been linked to levofloxacin, which is frequently given for bacterial prophylaxis in these patients [48]. Hypervirulent strains of Clostridium difficile, including the
Table 11.1 Bacterial infections following allo-HSCT

\begin{tabular}{|c|c|c|}
\hline Bacterial pathogens & Predisposing risks & $\begin{array}{l}\text { Clinical } \\
\text { manifestations }\end{array}$ \\
\hline Streptococcus viridans & $\begin{array}{l}\text { Neutropenia, oral } \\
\text { mucositis }\end{array}$ & Bacteremia \\
\hline $\begin{array}{l}\text { Streptococcus } \\
\text { pneumoniae }\end{array}$ & $\begin{array}{l}\text { Graft-versus-host } \\
\text { disease (GVHD), lack } \\
\text { of immunization }\end{array}$ & $\begin{array}{l}\text { Pneumonia, } \\
\text { meningitis, sepsis }\end{array}$ \\
\hline Enterococcus species & $\begin{array}{l}\text { Cephalosporin use, } C \text {. } \\
\text { difficile infection }\end{array}$ & Bacteremia \\
\hline Staphylococcus aureus & $\begin{array}{l}\text { Central venous lines } \\
(\mathrm{CVL}) \text {, colonization }\end{array}$ & $\begin{array}{l}\text { Bacteremia, } \\
\text { pneumonia, soft } \\
\text { tissue infection }\end{array}$ \\
\hline $\begin{array}{l}\text { Coagulase-negative } \\
\text { staphylococcus }\end{array}$ & CVL & Bacteremia \\
\hline Escherichia coli & $\begin{array}{l}\text { Neutropenia, } \\
\text { mucositis }\end{array}$ & $\begin{array}{l}\text { Bacteremia, } \\
\text { pneumonia }\end{array}$ \\
\hline Klebsiella pneumoniae & $\begin{array}{l}\text { Neutropenia, } \\
\text { mucositis }\end{array}$ & $\begin{array}{l}\text { Bacteremia, } \\
\text { pneumonia }\end{array}$ \\
\hline $\begin{array}{l}\text { Pseudomonas } \\
\text { aeruginosa }\end{array}$ & $\begin{array}{l}\text { Neutropenia, } \\
\text { mucositis }\end{array}$ & $\begin{array}{l}\text { Bacteremia, } \\
\text { pneumonia, } \\
\text { ecthyma }\end{array}$ \\
\hline $\begin{array}{l}\text { Stenotrophomonas } \\
\text { maltophilia }\end{array}$ & $\begin{array}{l}\text { CVL, prior broad- } \\
\text { spectrum antibiotic } \\
\text { exposure }\end{array}$ & Bacteremia \\
\hline Acinetobacter species & $\begin{array}{l}\text { CVL, prior broad- } \\
\text { spectrum antibiotic } \\
\text { exposure }\end{array}$ & $\begin{array}{l}\text { Bacteremia, } \\
\text { pneumonia }\end{array}$ \\
\hline Achromobacter species & $\begin{array}{l}\text { CVL, prior broad- } \\
\text { spectrum antibiotic } \\
\text { exposure }\end{array}$ & Bacteremia \\
\hline $\begin{array}{l}\text { Anaerobic bacteria (e.g., } \\
\text { Clostridium septicum, } \\
\text { Bacteroides species) }\end{array}$ & $\begin{array}{l}\text { Neutropenia, } \\
\text { mucositis }\end{array}$ & $\begin{array}{l}\text { Bacteremia, } \\
\text { necrotizing } \\
\text { enterocolitis, } \\
\text { typhlitis }\end{array}$ \\
\hline Clostridium difficile & $\begin{array}{l}\text { Antibiotic exposure, } \\
\text { GVHD, local } \\
\text { epidemiology, } \\
\text { previous } C \text {. difficile } \\
\text { infection }\end{array}$ & $\begin{array}{l}\text { Colitis, } \\
\text { megacolon, } \\
\text { secondary } \\
\text { bacteremia }\end{array}$ \\
\hline
\end{tabular}

epidemic North American pulse-field gel electrophoresis type 1 (NAP1) and ribotype 027/toxinotype III strains, have specifically been associated with moxifloxacin and other members of the fluoroquinolone class [49, 50]. An association between Clostridium difficile colitis and subsequent GVHD has also been reported [46]. The colitis may be severe, often relapses, and may also serve as a source for secondary bloodstream infections.

The risk of infection and bacteremia during this neutropenic pre-engraftment period is reduced by the use of prophylactic antibiotics. In general fluoroquinolones, usually levofloxacin, are the preferred agents [51]. Prophylaxis should start with the stem cell infusion and should continue until the resolution of the neutropenia or the initiation of antibiotic therapy for neutropenic fever. Several metaanalyses have demonstrated decreased infection-associated morbidity, mortality, as well as cost benefit, with the use of 
prophylactic antibacterials [52-54]. These agents do, however, increase the risk for selection of resistant bacteria and Clostridium difficile-associated disease [55].

\section{Infection During the Early Post-engraftment Period}

During the early period after engraftment, the risk of bacterial infections and bacteremia is reduced but ongoing. Risk is increased by general debility, by the presence of renal or hepatic dysfunction, and by the presence of GVHD. Central venous lines are often the source. Most of the patients by this time will have received antibiotic courses making them more likely to be infected with resistant pathogens. Staphylococci, enterococci (often vancomycin resistant), and nonfermenting Gram-negatives such as Stenotrophomonas maltophilia and Acinetobacter are frequent pathogens [38]. By virtue of their T-cell immunosuppression, these patients are also particularly susceptible to Listeria and Legionella if exposed $[56,57]$.

\section{Infection During the Late Post-engraftment Period}

During the late period following engraftment, the main predisposing factor for infection is the presence of GVHD. Many patients have B-cell dysfunction and are functionally asplenic $[58,59]$. They are thus vulnerable to serious infections with encapsulated bacteria, most notably Streptococcus pneumoniae, with pneumonia as the usual source [36, 60, 61]. Some patients are hypogammaglobulinemic, further increasing their risk. Less common are infections due to mycobacteria and Nocardia. Case reports suggest a global incidence of nontuberculous mycobacterial infections in allo-HSCT recipients ranging from $0.4 \%$ to $4.9 \%$ [37, 62-66]. Tuberculosis in this patient population, however, ranges from $0.0014 \%$ to $3 \%$ in the United States to as high as $8.5 \%$ in Taiwan [67-70]. Systemic nocardiosis is rare, and one center reported a cumulative incidence of $1.75 \%$; cases were all observed in patients with extensive chronic GVHD [71].

Preventive strategies include vaccination with the heptavalent conjugate pneumococcal vaccine at 3-6 months post-engraftment for all patients [51]. Immunogenicity of this vaccine, however, appears to be related to immune reconstitution, particularly in allo-HSCT recipients aged 50 and over. In this population, improved vaccine response has been associated with CD4 $>200$ cells $/ \mu \mathrm{L}, \mathrm{IgG}>500 \mathrm{mg} / \mathrm{dL}$, and phytohemagglutinin within $60 \%$ of the lower limit of normal [72]. Patients with active GVHD should also receive antibiotic prophylaxis aimed at pneumococcus. Penicillin V usually suffices, but trimethoprim/sulfamethoxazole or dox- ycycline may also be considered depending on local resistance patterns. For patients who are severely hypogammaglobulinemic (<400 $\mathrm{mg} \mathrm{IgG}$ ), regular infusions of intravenous immunoglobulin (IVIG) can be considered. Meticulous care of central venous catheters is mandatory $[51,73]$.

\section{Clostridium Difficile}

Clostridium difficile can occur at any time, though the risk is greatest during periods of hospitalization. Risk is increased in proportion to antibiotic exposure, especially perhaps to fluoroquinolones, by the presence of GVHD and of course by nosocomial risks, e.g., during an outbreak. Relapses are common after treatment.

\section{Viral Infections}

Viral pathogens are a significant source of morbidity and mortality after allo-HSCT [74]. Allo-HSCT recipients are affected by a wide range of viruses, either through primary infection, donor-derived infection, or reactivation of latent virus.

\section{Cytomegalovirus}

CMV continues to be one of the most important pathogens in this group. It is estimated that about $50 \%$ of the population in the United States is latently infected with CMV [75]. In other places in the world, including developing nations, the prevalence is even higher [76, 77].

Prior to widespread use of anti-CMV prophylaxis, approximately $80 \%$ of seropositive allo-HSCT recipients developed CMV reactivation, usually in the first 3 months after transplantation [78]. Despite prophylaxis with either ganciclovir or valganciclovir, the incidence of CMV reactivation ranges between $20 \%$ and $50 \%$, with episodes increasingly occurring after prophylaxis is finished (late CMV) [79-83]. Approximately $6-18 \%$ of allo-HSCT recipients with CMV reactivation develop disease [79, 80, 83]. Clinical manifestations of CMV disease are variable and include interstitial pneumonia, enteritis, hepatitis, retinitis, encephalitis, and a CMV syndrome that includes cytopenia and fevers. CMV-related mortality is on average $40-50 \%$, but can be as high as $86 \%$ in cases of severe pneumonia [83]. In addition to its direct end-organ effects, CMV disease is also associated with increased bacterial, fungal, and other viral infections [84].

The classic and most important risk factor for CMV reactivation is the serostatus of the recipient and donor, with a CMV-infected (seropositive) patient receiving a graft from a CMV-naïve (seronegative) donor considered the highest risk. 
Additional risk factors include total body radiation in the conditioning phase, development of acute and chronic GVHD, T-cell-depleting therapies, steroids at doses greater than $1 \mathrm{mg} / \mathrm{kg}$ per day, and the use of mismatched or unrelated donors [78, 79].

Diagnosis of CMV disease remains clinically challenging given the varied and nonspecific presentations. Although PCR analysis of CMV DNA in the serum has become the mainstay of diagnosis, no absolute cutoff in viremia exists for differentiation between infection and disease. The presence of viremia does not automatically indicate disease although studies have shown that the likelihood of disease is high when levels above 10,000 copies/mL are found [85]. Conversely, disease does not always correlate with viremia, especially in cases of gastrointestinal involvement. With the introduction of international units, better studies to correlate disease and viremia will be possible in the future.

Intravenous ganciclovir is first-line therapy for CMV disease in allo-HSCT recipients. In non-severe cases, including asymptomatic viremia, oral valganciclovir can be used. Due to toxicities, foscarnet and cidofovir are considered secondline drugs and reserved for treatment failure due to GCV resistance or in situations where GCV is not tolerated. It is recommended that continuing treatment for 14-21 days after CMV DNA is no longer detectable in serum, followed by 1-3 months of maintenance therapy [86]. CMV immunoglobulins have been studied and in general are reserved for severe cases, especially pneumonia, or lack of response to antiviral therapy [87]. Recent studies have suggested that CMV-specific T-cell administration can be effective in the prophylaxis and treatment of CMV [88].

Although risk-stratified prophylaxis with oral valganciclovir can be effective, problems with toxicity, especially bone marrow suppression, preclude it from being a standard approach. An alternative approach involves frequent serum CMV PCR monitoring and initiation of treatment if viremia is detected. This preemptive approach is usually more logistically difficult and leads to higher rates of CMV reactivation [51]. An elusive goal for many decades, the search for a vaccine has recently shown promising results around glycoprotein B and phosphoprotein 65 epitopes $[89,90]$.

\section{Epstein-Barr Virus (EBV)}

In the United States and worldwide, it is estimated that almost $95 \%$ of adults demonstrate past infection with EBV. The spectrum of EBV-related diseases includes asymptomatic viremia, a viral syndrome with fevers and neutropenia, oral hairy leukoplakia, and rarely meningoencephalitis. More importantly, EBV is also associated with $50-70 \%$ of cases of PTLD in allo-HSCT recipients [91].

PTLD usually occurs in the first year after transplant and arises when EBV-specific T-lymphocytes are depleted, allowing for unchecked proliferation of donor-derived mono- clonal or polyclonal B cells [92]. The spectrum of PTLD includes extranodal lymphocyte infiltration to high-grade B-cell lymphoma and varies from an indolent to fulminant presentation. Although the overall incidence of EBV-related PTLD in this population is approximately $1 \%$ (up to $2.8 \%$ in children), mortality can be as high as 50-90\% [93]. Risk factors include age $>50$; recipients of mismatched, matched unrelated, or T-cell-depleted transplants; acute and chronic GVHD; and use of T-cell-depleting agents such as thymoglobulin and alemtuzumab [92].

Treatment options range from reduced immunosuppression to chemotherapeutic agents such as rituximab or CHOP. Antiviral agents have a limited role in the treatment or prevention of EBV-PTLD. Given that persistent or increasing EBV viremia usually precedes PTLD, preemptive treatment with rituximab may reduce the risk of progression to PTLD [94, 95].

\section{Herpes Simplex Virus (HSV)}

More than $50 \%$ of US adults are latently infected with HSV-1 [96]. In allo-HSCT recipients who do not received antiviral prophylaxis, the rate of reactivation can be as high as $80 \%$ and often occurs earlier, 2-3 weeks post-engraftment, than other herpesviruses [97, 98]. Clinical manifestations most commonly include oral-labial lesions and esophagitis, but can be varied and cause bone marrow suppression, keratitis, pneumonia, hepatitis, as well as meningoencephalitis [99104]. HSV-2, on the other hand, is less frequent and is usually involved with perineal lesions only. Recurrent episodes of either HSV-1 or 2 infections may warrant suppressive therapy [51].

\section{Varicella Zoster Virus (VZV)}

Similar to HSV, reactivation is the most common cause of VZV-related disease after allo-HSCT, occurring in about $16 \%$ of patients in the first year after transplant [105]. Since anti-HSV or CMV prophylaxis is effective against VZV, reactivation usually occurs after prophylaxis has stopped, although breakthrough can also occur $[105,106]$. GVHD is a major risk factor for VZV reactivation [107]. Clinical manifestations include either classic or multi-dermatomal shingles with lesions usually taking longer to heal that in immunocompetent patients. Disseminated VZV is a rare but severe occurrence, which can involve the lungs, liver, and CNS [108].

\section{Human Herpesvirus (HHV) 6, 7, and 8}

HHV-6 reactivation is common early post allo-HSCT, ranging from $36 \%$ to $47 \%$ of patients in the first month [109, 110]. The vast majority of cases range from asymptomatic viremia to fevers and transient marrow suppression, but patients can infrequently develop severe disease, including encephalitis, hepatitis, and pneumonitis. Posttransplant acute 
limbic encephalitis [111] is a form of CNS disease in alloHSCT recipients that is related to HHV-6 reactivation [112]. In addition to its direct effects, HHV-6 viremia has been found to increase delayed engraftment and GVHD as well as predispose patients to CMV and EBV reactivation [109]. Risk factors for HHV-6 reactivation include cord blood transplantation as well HLA mismatch [113]. Ganciclovir has activity against HHV-6 and is used for treatment [114]. Screening and preventative measures have not been developed.

HHV-7 viremia is also a common occurrence, but its association with post-HSCT disease is not well documented at this time. Reports of CNS disease associated with this virus have been reported [115].

HHV-8 can be transmitted to seronegative recipients, but clinical manifestations of viremia are also not well documented at this time, although it may possibly be related to fever, rash, mild hepatitis, and bone marrow aplasia. Unlike solid organ transplantation, cases of Kaposi's sarcoma are very rare [116].

\section{Adenovirus (ADV)}

Besides reactivation of latent infection, allo-HSCT recipients are susceptible to transmission of ADV via the stem cell graft as well as primary acquisition of any of the other $>50$ serotypes. About $12 \%$ of allo-HSCT recipients are affected by ADV reactivation, most of which are children under 5 years of age [117]. Reactivation usually occurs between 30 and 90 days posttransplant. Besides young age, risk factors for reactivation include severe GVHD, high-dose steroids, as well as use of unrelated cord blood [74]. In recipients with ADV viremia, approximately 40-50\% develop disease, which ranges from a viral syndrome (fever, elevated liver enzymes, and pancytopenia) to pneumonitis, nephropathy, hemorrhagic cystitis, colitis, myocarditis, and CNS disease. Mortality in the setting of ADV disease is estimated to be around $22 \%$ [117].

Diagnosis is usually a combination of high clinical suspicion, serum ADV quantitative PCR, and histology. Treatment is not well defined but usually consists of reduced immunosuppression and cidofovir, which has a high incidence of nephrotoxicity [118]. Preventative measures are also not well defined.

\section{Respiratory Viruses}

With continuously improving detection techniques, respiratory viral pathogens have been increasingly recognized as significant sources of morbidity and mortality among recipients of allo-HSCT. These include, among others, influenza [119], parainfluenza [120], RSV [121], human metapneumovirus [122], as well as multiple strains of rhinoviruses, coronaviruses, and bocaviruses [123, 124]. Both community and nosocomial outbreaks are responsible for majority of infec- tions, and rates of respiratory viral infections among alloHSCT recipients undergo seasonal variation, much like the general population [125]. Estimates vary, but studies have shown that influenza (both A and B), parainfluenza, and RSV are the most common causes of viral respiratory infections [125]. Risk factors include GVHD, lymphopenia, and the presence of children younger than 12 years of age at home. Diagnosis involves clinical suspicion and RT-PCR. Mortality is variable and is usually associated with complications such as respiratory failure and bacterial or fungal superinfection. Preventative measures include vaccination, hand washing, and isolation measures in the setting of outbreaks. Besides anti-influenza drugs, antiviral therapy for most other respiratory viruses remains largely unproven $[119,120]$.

\section{Hepatitis B Virus}

The main risk with hepatitis B virus is reactivation of previously resolved infection, which can occur in up to $20 \%$ of cases if prophylaxis is not instituted [126]. Among those who reactivate, liver failure can be a rare complication. It is recommended that both recipients and donors be checked for hepatitis B serologies prior to HSCT and appropriate therapeutic or prophylactic measures taken [127].

\section{Polyoma Viruses (BK and JC)}

Although more commonly affecting renal transplant recipients, BK virus reactivation has also been described to cause both hemorrhagic cystitis and nephropathy in allo-HSCT recipients [128-131]. JCV-related progressive multifocal leukoencephalopathy (PML) is a rare but well-described complication in allo-HSCT recipients with dismal prognosis [132].

\section{Fungal Infections}

Invasive fungal infections (IFIs) are a major cause of morbidity and mortality among HSCT recipients. Individuals undergoing allo-HSCT are at higher risk for developing IFIs compared to recipients of autologous grafts, largely owing to delayed engraftment and GVHD. The epidemiology of IFIs in HSCT recipients remains dynamic. Since the 1990s, there has been a decrease in the incidence of invasive candidiasis among HSCT recipients due to the more widespread use of fluconazole prophylaxis; however, IFIs due to Aspergillus and other filamentous molds remain a significant concern.

\section{Candida}

Candida species commonly inhabit the skin and mucosa of the gastrointestinal tract, and disruption of the integrity of either mucosal barrier can lead to invasive candidiasis. In the 
setting of allo-HSCT, invasive candidiasis typically results from mucositis of the gastrointestinal tract incurred during conditioning. Additional risk factors for invasive candidiasis include HLA mismatch, recipient age, prolonged neutropenia, GVHD, gastrointestinal tract colonization, and CMV disease [133, 134].

In the early 1990s, two large trials demonstrated a significant decrease in candidiasis with the use of fluconazole prophylaxis, and its administration through 75 days posttransplant was later shown to significantly reduce mortality among alloHSCT recipients [135-137]. This prompted the widespread use of fluconazole prophylaxis in the early posttransplant period. More recent data from the Prospective Antifungal Therapy (PATH) Alliance registry, however, reported a $28 \%$ and $23 \%$ incidence of invasive candidiasis in allo-HSCT recipients from matched-related and matched-unrelated donors, respectively [138]. While Candida albicans accounted for over half of all episodes of invasive candidiasis in HSCT recipients in the 1980s, invasive candidiasis caused by azoleresistant Candida species such as C. glabrata and C. krusei has increased since the $1990 \mathrm{~s}$, which may reflect the routine use of fluconazole prophylaxis [28-30, 137, 138].

Invasive candidiasis in allo-HSCT recipients most commonly presents as fungemia or hepatosplenic candidiasis. Candidemia occurs in approximately $3 \%$ of HSCT recipients and may be accompanied by sepsis, a discreet palpable vasculitic rash, and/or end-organ involvement including but not limited to meningitis, endophthalmitis, and endocarditis [139]. In contrast, hepatosplenic candidiasis, or chronic disseminated candidiasis, results from invasion of Candida species into the portal vasculature with subsequent seeding of the liver and/or spleen during periods of neutropenia. While the exact incidence of hepatosplenic candidiasis remains unknown, one autopsy study identified hepatic candidal infection in 9\% of HSCT recipients [140]. Patients typically present with fever and an elevated alkaline phosphatase level following neutrophil recovery. Blood cultures tend to be negative in this setting, but computed tomography of the abdomen demonstrates multiple lesions in the liver and spleen; such lesions decrease in size with recurrent neutropenia, indicating that hepatosplenic candidiasis results from a systemic inflammatory response. Biopsy is required for definitive diagnosis, especially because other IFIs and malignancy can result in a similar clinical syndrome.

The diagnosis of invasive candidiasis remains challenging, particularly because conventional blood cultures may only have a sensitivity of $50 \%$ in those with deep fungal infection [141]. Newer diagnostic assays, including the beta-D-glucan test, which detects beta-glucans in the cell wall of molds and yeasts except zygomycetes and cryptococci, may be valuable in the diagnosis of invasive candidiasis. One recent study demonstrated a sensitivity and specificity of $87.5 \%$ and $85.5 \%$, respectively, of this assay. The mannan antigen and antibody and the Cand-Tec Candida antigen assays have demonstrated lower sensitivities than the beta-D-glucan assay $(58.9 \%, 62.5 \%$, and $13 \%$, respectively) [142].

Given the prevalence of azole-resistant Candida species in neutropenic patients, particularly C. glabrata and C. krusei, management of invasive candidiasis in allo-HSCT recipients should include amphotericin B or an echinocandin such as caspofungin, micafungin, or anidulafungin. Several studies have demonstrated comparable efficacy between both antifungal classes; however, echinocandins have been associated with a more favorable toxicity profile [143, 144]. Voriconazole may be used in situations where additional mold coverage is desired; however, since voriconazole resistance has been seen in $3 \%$ of Candida infections in solid organ and HSCT recipients, this agent should not be used unless susceptibility of the isolate is confirmed [145, 146]. As the majority of cases of hepatosplenic candidiasis are caused by $C$. albicans, clinically stable patients may receive fluconazole. Those who are acutely ill or who have relapsed disease should receive 1-2 weeks of induction with liposomal amphotericin B or an echinocandin followed by fluconazole. Duration of therapy for hepatosplenic candidiasis is dependent upon resolution of visceral lesions, typically 3-6 months. Chronic suppressive therapy may be used in individuals at high risk for recurrence, including those with GVHD [146].

\section{Invasive Mold Infections}

Aspergillus and other molds are ubiquitous environmental pathogens. HSCT recipients are at high risk of infection with these organisms, which are largely acquired via inhalation of conidia that are inadequately cleared in the setting of immunosuppression. Less common routes of infection include invasion of the gastrointestinal tract or cutaneous inoculation.

\section{Aspergillus}

Invasive aspergillosis is the most frequent IFI encountered among allo-HSCT recipients. Data from the PATH Alliance demonstrated an incidence of invasive aspergillosis of $53.5 \%$ and $59.8 \%$ in recipients of matched-related donor and matched-unrelated donor transplants, respectively [138]. While both autologous and allo-HSCT recipients are at risk for the development of invasive aspergillosis, prolonged neutropenia, as well as GVHD, and its treatment contribute to higher incidences of invasive aspergillosis among allo-HSCT recipients [147, 148].

The onset of invasive aspergillosis following HSCT occurs in a bimodal fashion, with the first peak noted within the first 40 days of transplantation [149] and corresponding to the period of neutropenia. The second peak occurs post- 
engraftment ("late period"), typically defined as $41+$ days following transplant, and tends to arise in the setting of acute or chronic GVHD [147, 148, 150]. Age >40 has been associated with the development of invasive aspergillosis at any time following transplantation, as have donor and recipient polymorphisms in various Toll-like receptors and genes regulating interleukin-1, interleukin-10 promoter, and plasminogen [147, 151-155]. Specifically, donor haplotype $1363 \mathrm{~T} / 1063 \mathrm{G}$, which contains two cosegregated single nucleotide polymorphisms in the Toll-like receptor 4 gene, has been associated with the development of invasive aspergillosis [151]. Single nucleotide polymorphisms in the chemokine ligand 10 (CXCL-10) gene have also been demonstrated to reduce dendritic cell CXCL-10 expression when exposed to Aspergillus germlings; these polymorphisms have also been associated with invasive aspergillosis following allo-HSCT [154]. Hematologic malignancies other than chronic myelogenous leukemia in the chronic phase, as well as aplastic anemia, myelodysplastic syndrome, mismatched donor, the use of cord blood, summer season, lack of laminar air flow, and local building construction, have been identified as risk factors for invasive aspergillosis in the early posttransplant period. The risk of invasive aspergillosis in the late posttransplant period increases in the setting of underlying multiple myeloma, use of T-celldepleted or CD34-selected stem cell products, neutropenia, lymphopenia, use of corticosteroids, CMV disease, respiratory virus infection, and GVHD [147, 148]. GVHD and CMV disease are the major risk factors for the development of invasive aspergillosis $>6$ months after transplantation [148]. The contribution of GVHD to the risk of invasive aspergillosis is highlighted by the fact that conditioning regimens do not appear to impact the incidence of this invasive fungal infection. While the period of neutropenia is shorter and the incidence of early invasive aspergillosis is less in non-myeloablative HSCT recipients, this group remains at highest risk in the late posttransplant period in conjunction with GVHD [12, 156-158].

Aspergillus fumigatus is the most commonly isolated species associated with invasive aspergillosis in allogeneic HSCT recipients; infections with $A$. niger, A. flavus, and A. terreus are less frequently encountered [147, 159]. The lungs represent the most commonly involved site of infection, though patients may develop sinusitis, CNS disease, and tracheobronchitis. Clinical presentation may be variable, but frequently includes fever, cough, chest pain, hemoptysis, and/or respiratory failure, and the presence of these symptoms should prompt CT of the chest. Lung lesions, with surrounding ground-glass halos, nodular infiltrates, and cavitations, are highly suggestive of pulmonary aspergillosis; however, radiographic findings can be variable in allo-HSCT recipients with concomitant GVHD and include focal infiltrates and/or bronchopneumonia [160]. Given the lack of specificity of symptoms and radiographic findings, prompt microbiologic diagnosis via bronchoscopy should be pursued. Diagnosis of invasive aspergillosis may also be facilitated with use of the Aspergillus galactomannan assay, which employs a doublesandwich enzyme immunoassay to detect the galactomannan component of the Aspergillus cell wall. While the sensitivity of the serum galactomannan assay has varied between studies, it has proven clinically useful for the diagnosis of invasive aspergillosis and monitoring of clinical response during therapy [161, 162]. The galactomannan assay on bronchoalveolar lavage fluid in patients with hematologic malignancies and HSCT recipients has demonstrated higher sensitivity than bronchoalveolar lavage culture, cytology, and the serum galactomannan assay [163]. Important caveats for the use of galactomannan testing include false negative results in individuals receiving concomitant antifungals, false positive results in children and patients receiving beta-lactams, particularly piperacillin-tazobactam, and cross-reactivity with plasmalyte [164-166]. The beta-D-glucan test, which detects beta-glucans in the cell wall of molds and yeasts except zygomycetes and cryptococci, may also be a valuable adjunctive screening test for invasive aspergillosis particularly in conjunction with the galactomannan assay, though the performance characteristics of the beta-D-glucan assay in the HSCT population have not yet been evaluated.

Empiric therapy for suspected invasive aspergillosis should include a mold-active azole or amphotericin B. The use of an echinocandin can also be entertained, though these agents are fungistatic, rather than fungicidal. Once the diagnosis of invasive aspergillosis has been confirmed, primary therapy should include voriconazole in most patients, as this agent has been associated with improved clinical outcomes and survival rates and less toxicity compared with amphotericin B [167, 168]. Voriconazole is also the preferred therapy for Aspergillus tracheobronchitis [168]. Combination therapy with an echinocandin and either amphotericin B or a mold-active azole may be more efficacious than voriconazole alone, however, particularly for salvage therapy [169, 170]. The duration of therapy in allogeneic HSCT recipients should be prolonged and continue at least until immunosuppressives, particularly corticosteroids, are completed.

Prevention of invasive aspergillosis in allogeneic HSCT recipients should include the use of high-efficiency particulate air (HEPA) filtration and/or laminar flow rooms during the pre-engraftment period. In addition, two recent studies have suggested that voriconazole may be appropriate secondary prophylaxis prior to HSCT in patients with previous IA $[171,172]$.

\section{Other Molds}

Mucor and Rhizopus species are the most commonly encountered zygomycetes in clinical practice, with an incidence of $8.5 \%$ and $5.9 \%$ in recipients of matched-related and matched- 
unrelated allo-HSCT, respectively [138]. Infection with these organisms results in mucormycosis, which can occur in the late posttransplant period and causes devastating sinoorbital, CNS, and gastrointestinal disease, as well as cutaneous lesions and fasciitis. Among HSCT recipients, risk factors for zygomycosis include HLA mismatch, prolonged neutropenia, corticosteroid use, iron overload, and GVHD $[173,174]$. Additionally, several studies have noted increasing numbers of zygomycosis cases among patients receiving voriconazole as either prophylaxis or treatment of invasive aspergillosis [32, 111, 175]. Whether this reflects azolerelated selective pressure remains unknown.

Fusarium species are environmental organisms, which cause infrequent but severe invasive fungal infection in HSCT recipients. Cases of fusariosis among HSCT recipients have been linked to contamination of central venous catheters and hospital water supply [176, 177]. Risk factors for fusariosis include underlying multiple myeloma and HLA mismatch. As with invasive aspergillosis, the onset of fusariosis occurs in a bimodal fashion; infection in the early posttransplant period is associated with prolonged neutropenia, and late infection is associated with T-cell depletion, corticosteroid use, and GVHD. Infection with Fusarium species can mimic invasive aspergillosis; however, patients with fusariosis are more likely to have positive blood cultures and multiple papular or ulcerated skin lesions compared to patients with invasive aspergillosis [176, 178].

Scedosporium apiospermum and Scedosporium prolificans have also been isolated in HSCT recipients; their disease spectrum is similar to invasive aspergillosis. Risk factors for Scedosporium infection include prolonged neutropenia and GVHD [159, 179, 180].

\section{Miscellaneous Infections}

\section{Pneumocystis Jirovecii (PJP)}

Due to effective prophylaxis, PCP has become a rare event among allo-HSCT recipients with retrospective studies showing incidence rates from $1.3 \%$ to $2.5 \%$ [181, 182]. PCP is usually a late occurrence, and risk factors include treatment for GVHD or cessation of PCP prophylaxis [183]. Despite effective treatment, mortality can be high if infection occurs early after transplant [184].

\section{Toxoplasmosis}

The majority of cases of toxoplasmosis in allo-HSCT recipients are due to reactivation of latent infection. In the United States, the incidence of toxoplasmosis has been reported to be as low as $0.25 \%$ [185], reflecting a low seroprevalence in the population [186]. In regions of the world with a higher seroprevalence, incidence rates of toxoplasmosis are predictably higher [187]. Disease usually occurs in the first 6 months after transplantation $[185,186]$. Besides seropositivity, the main risk factor for reactivation is intensification of immunosuppression due to GVHD [186]. The most common clinical presentation is encephalitis, which usually presents with focal neurological deficits. Extra-CNS forms of toxoplasmosis include pneumonitis, chorioretinitis, and myocarditis. Diagnosis of toxoplasmosis in any of the above manifestations requires a high clinical suspicion. A toxoplasma PCR can be obtained in serum and tissue such as CSF and vitreous fluid [188, 189]. First-line treatment includes extensive treatment with pyrimethamine and sulfadiazine. Despite best efforts mortality in allo-HSCT recipients remains high $[185,190]$. Prophylaxis is usually accomplished with trimethoprim/sulfamethoxazole [191].

\section{Strongyloides}

Strongyloides stercoralis can latently infect auto-HSCT recipients who previously lived or visited endemic areas (tropical and subtropical region worldwide), even many decades earlier. In the setting of immunosuppression, the parasite's life cycle is accelerated and cause hyperinfection and disseminated disease [192]. Clinical manifestations include intestinal obstruction, respiratory failure including alveolar hemorrhage, bacterial sepsis, or meningitis [193]. Because of delays in diagnosis, infections can be devastating and carry high mortality. Patients from endemic areas should be serologically screened and treated with ivermectin prior transplant [193].

\section{Preventative Strategies}

Like solid organ transplant recipients, allo-HSCT recipients can benefit from measures aimed to prevent infectious complications in the posttransplant period. These can include infection control practices in hospitals and outpatient clinics as well as guidelines for the prevention of opportunistic infections.

The CDC/IDSA and ASBMT have published extensive evidence-based infection control guidelines that include specific practices regarding room ventilation, isolation and barrier precautions, cleaning, hand hygiene, equipment disinfection, plants, patient skin and oral care, prevention of intravascular catheter-related infections, construction and renovations, as well as healthcare workers [194].

In terms of specific infections, guidelines from the CDC were published in 2000. Because many of these organisms not only involve reactivation of latent infection in the recipient but can also be donor-derived, both donors and recipients should be universally tested for CMV, EBV, HIV I/II, HTLV I/II (although this is not done in all centers), hepatitis B and C, syphilis, and M. tuberculosis (in donor only if from endemic country). Additionally, all recipients should be tested for HSV I/II, VZV, and Toxoplasma. Potential donors and recipients 
Table 11.2 Pretransplant screening in candidate allo-HSCT donors and recipients

\begin{tabular}{|c|c|}
\hline Donor screening & Recipient screening \\
\hline \multicolumn{2}{|l|}{ Standard } \\
\hline CMV IgG & CMV IgG \\
\hline EBV VCA IgG & EBV VCA IgG \\
\hline VZV IgG & HSV I/II IgG \\
\hline HIV Ab and NAT & VZV IgG \\
\hline HTLV I//II Ab & HIV Ab and NAT \\
\hline $\begin{array}{l}\text { Hepatitis B surface Ag and core } \\
\mathrm{Ab}\end{array}$ & HTLV I/II Ab \\
\hline Hepatitis C Ab, NAT & $\begin{array}{l}\text { Hepatitis B surface Ag and core } \\
\mathrm{Ab}\end{array}$ \\
\hline Syphilis screening (RPR) & $\begin{array}{l}\text { Hepatitis C Ab, NAT } \\
\text { Syphilis screening (RPR) } \\
\text { Latent Tb screening (PPD or } \\
\text { IGRA) }\end{array}$ \\
\hline \multicolumn{2}{|l|}{ Optional (if risk factors are present) } \\
\hline Hepatitis B NAT & Hepatitis B NAT \\
\hline West Nile virus $A b$ & West Nile virus $A b$ \\
\hline Toxoplasma $\mathrm{Ab}$ & Toxoplasma $\mathrm{Ab}$ \\
\hline Strongyloides $\mathrm{Ab}$ & Strongyloides Ab \\
\hline Trypanosoma cruzi & Trypanosoma cruzi \\
\hline Leishmania Ab/PCR & Coccidioides Ab \\
\hline Babesia Ab & Histoplasma $\mathrm{Ab}$ \\
\hline Rickettsia Ab & Brucella Ab \\
\hline Coxiella burnetii $\mathrm{Ab}$ & \\
\hline
\end{tabular}

Table 11.3 Recommended and optional vaccination of allo-HSCT recipients [195]

\begin{tabular}{|c|c|c|}
\hline Vaccine & $\begin{array}{l}\text { Comments on use after } \\
\text { allo-HSCT }\end{array}$ & $\begin{array}{l}\text { Time } \\
\text { post-HSCT to } \\
\text { initiate } \\
\text { vaccine }\end{array}$ \\
\hline \multicolumn{3}{|l|}{ Recommended } \\
\hline $\begin{array}{l}\text { Pneumococcal } \\
\text { conjugate }(\mathrm{PCV})\end{array}$ & $\begin{array}{l}\text { 3-4 doses, a fourth dose with } \\
\text { PPSV23a may be beneficial }\end{array}$ & $3-6$ months \\
\hline $\begin{array}{l}\text { Tetanus, } \\
\text { diphtheria, } \\
\text { acellular } \\
\text { pertussis }\end{array}$ & $\begin{array}{l}3 \text { doses, DTaP preferred over } \\
\text { Tdap }\end{array}$ & 6-12 months \\
\hline $\begin{array}{l}\text { Haemophilus } \\
\text { influenzae } \\
\text { conjugate }\end{array}$ & 3 doses & 6-12 months \\
\hline $\begin{array}{l}\text { Meningococcal } \\
\text { conjugate }\end{array}$ & $\begin{array}{l}1 \text { dose, follow country } \\
\text { recommendations for general } \\
\text { population }\end{array}$ & 6-12 months \\
\hline Inactivated polio & 3 doses & 6-12 months \\
\hline $\begin{array}{l}\text { Recombinant } \\
\text { hepatitis B }\end{array}$ & $\begin{array}{l}3 \text { doses, follow country } \\
\text { recommendations for general } \\
\text { population }\end{array}$ & 6-12 months \\
\hline $\begin{array}{l}\text { Inactivated } \\
\text { influenza }\end{array}$ & Yearly & 4-6 months \\
\hline $\begin{array}{l}\text { Measles, } \\
\text { mumps, rubella } \\
\text { (live) }\end{array}$ & $\begin{array}{l}\text { 1-2 doses, all children and } \\
\text { measles seronegative adults, not } \\
\text { recommended if active GVHD or } \\
\text { on immunosuppression }\end{array}$ & $>24$ months \\
\hline \multicolumn{3}{|l|}{ Optional } \\
\hline Hepatitis A & $\begin{array}{l}\text { Follow country recommendations } \\
\text { for general population }\end{array}$ & 12 months \\
\hline
\end{tabular}

Table 11.3 (continued)

\begin{tabular}{|c|c|c|}
\hline $\begin{array}{l}\text { Varicella } \\
\text { (Varivax, live) }\end{array}$ & $\begin{array}{l}\text { Limited data regarding safety and } \\
\text { efficacy. Not recommended if } \\
\text { active GVHD or on } \\
\text { immunosuppression }\end{array}$ & $>24$ months \\
\hline $\begin{array}{l}\text { Human } \\
\text { papillomavirus }\end{array}$ & $\begin{array}{l}\text { Follow country recommendations } \\
\text { for general population }\end{array}$ & No data \\
\hline $\begin{array}{l}\text { Yellow fever } \\
\text { (live) }\end{array}$ & $\begin{array}{l}\text { Limited data regarding safety and } \\
\text { efficacy. The risk-benefit balance } \\
\text { may favor use of the vaccine in } \\
\text { patients residing in or traveling to } \\
\text { endemic areas }\end{array}$ & $>24$ months \\
\hline Rabies & $\begin{array}{l}\text { Appropriate for use in HCT } \\
\text { recipients with potential } \\
\text { occupational exposures to rabies. } \\
\text { Postexposure administration of } \\
\text { rabies vaccine with human rabies } \\
\text { Ig can be administered any time } \\
\text { after HCT, as indicated }\end{array}$ & $12-24$ months \\
\hline $\begin{array}{l}\text { Tick-borne } \\
\text { encephalitis }\end{array}$ & $\begin{array}{l}\text { According to local policy in } \\
\text { endemic areas }\end{array}$ & No data \\
\hline $\begin{array}{l}\text { Japanese B } \\
\text { encephalitis }\end{array}$ & $\begin{array}{l}\text { According to local policy when } \\
\text { residing in or travelling to } \\
\text { endemic areas }\end{array}$ & No data \\
\hline
\end{tabular}

Adapted and printed by permission from Macmillan Publishers Ltd.: Nature Publishing Group, Bone Marrow Transplantation, Vaccination of hematopoietic cell transplant recipients, Ljungman P, Cordonnier C, Einsele H, Englund J, Machado CM, et al.; Center for International Blood and Marrow Transplant Research; National Marrow Donor Program; European Blood and Marrow Transplant Group; American Society of Blood and Marrow Transplantation; Canadian Blood and Marrow Transplant Group; Infectious Disease Society of America; Society for Healthcare Epidemiology of America; Association of Medical Microbiology and Infectious Diseases Canada; Centers for Disease Control and Prevention Vol. 44/No. 8, pages 521-526, (c) 2009 Contraindicated vaccines: BCG (live), oral polio (live), intranasal live influenza, cholera (live), typhoid (live and IM), Rotavirus, zoster vaccine (Zostavax, live)

aPPV23: 23-valent pneumococcal vaccine

should also be tested for Strongyloides and Trypanosoma cruzi if they have epidemiologic risks. Patients with evidence of syphilis, Strongyloides, or latent tuberculosis infection should be treated in the pretransplant period (see Table 11.2).

Vaccinations are an important component of disease prevention. Because of predictable decline in antibody titers posttransplant, it is recommended that recipients be revaccinated in the post-engraftment at the appropriate time (see Table 11.3) [195].

Prophylaxis in the posttransplant period is usually aimed at the most common and predictable organisms. A discussion of strategies to prevent CMV is beyond the scope of this chapter but includes either preemptive treatment in cases of CMV viremia or universal prophylaxis for those at risk for CMV reactivation. Recipients not at risk for CMV should receive acyclovir for HSV prophylaxis. PCP and Toxoplasma prophylaxis is accomplished with sulfamethoxazole/trimethoprim for 6-13 months, although this practice varies when taking into consideration the myelosuppressive effects of 
this drug combination. Dapsone, atovaquone, and pentamidine are alternatives for PCP prophylaxis. Of those, only atovaquone has activity against Toxoplasma as well. Many centers also institute bacterial and fungal prophylaxis in the peri-transplant period until neutropenia resolves.

\section{References}

1. Bodey GP, Buckley M, Sathe YS, Freireich EJ. Quantitative relationships between circulating leukocytes and infection in patients with acute leukemia. Ann Intern Med. 1966;64(2):328-40.

2. Wingard JR, Leather HL. Empiric antifungal therapy for the neutropenic patient. Oncology (Williston Park). 2001;15(3):351-63. discussion 363-4, 367-9

3. Cornely OA, Maertens J, Winston DJ, Perfect J, Ullmann AJ, Walsh TJ, et al. Posaconazole vs. fluconazole or itraconazole prophylaxis in patients with neutropenia. N Engl J Med. 2007;356(4):348-59.

4. Lortholary O, Gangneux JP, Sitbon K, Lebeau B, de Monbrison F, Le Strat Y, et al. Epidemiological trends in invasive aspergillosis in France: the SAIF network (2005-2007). Clin Microbiol Infect. 2011;17(12):1882-9.

5. Kontoyiannis DP, Chamilos G, Lewis RE, Giralt S, Cortes J, Raad II, et al. Increased bone marrow iron stores is an independent risk factor for invasive aspergillosis in patients with high-risk hematologic malignancies and recipients of allogeneic hematopoietic stem cell transplantation. Cancer. 2007;110(6):1303-6.

6. Pagano L, Akova M, Dimopoulos G, Herbrecht R, Drgona L, Blijlevens N. Risk assessment and prognostic factors for mouldrelated diseases in immunocompromised patients. J Antimicrob Chemother. 2011;66(Suppl 1):i5-14.

7. Hersh EM, Carbone PP, Wong VG, Freireich EJ. Inhibition of the primary immune response in man by anti-metabolites. Cancer Res. 1965;25(7):997-1001.

8. Filipovich A. Hematopoietic cell transplantation for correction of primary immunodeficiencies. Bone Marrow Transplant. 2008;42(Suppl 1):S49-52.

9. Smith AR, Gross TG, Baker KS. Transplant outcomes for primary immunodeficiency disease. Semin Hematol. 2010;47(1):79-85.

10. Scott BL, Park JY, Deeg HJ, Marr KA, Boeckh M, Chauncey TR, et al. Pretransplant neutropenia is associated with poor-risk cytogenetic features and increased infection-related mortality in patients with myelodysplastic syndromes. Biol Blood Marrow Transplant. 2008;14(7):799-806.

11. Verschraegen CF, van Besien KW, Dignani C, Hester JP, Andersson BS, Anaissie E. Invasive Aspergillus sinusitis during bone marrow transplantation. Scand J Infect Dis. 1997;29(4):436-8.

12. Junghanss C, Marr KA, Carter RA, Sandmaier BM, Maris MB, Maloney DG, et al. Incidence and outcome of bacterial and fungal infections following nonmyeloablative compared with myeloablative allogeneic hematopoietic stem cell transplantation: a matched control study. Biol Blood Marrow Transplant. 2002;8(9):512-20.

13. Nucci M, Andrade F, Vigorito A, Trabasso P, Aranha JF, Maiolino A, De Souza CA. Infectious complications in patients randomized to receive allogeneic bone marrow or peripheral blood transplantation. Transpl Infect Dis. 2003;5(4):167-73.

14. Eyrich M, Lang P, Lal S, Bader P, Handgretinger R, Klingebiel T, et al. A prospective analysis of the pattern of immune reconstitution in a paediatric cohort following transplantation of positively selected human leucocyte antigen-disparate haematopoietic stem cells from parental donors. Br J Haematol. 2001;114(2):422-32.

15. Safdar A, Rodriguez GH, De Lima MJ, Petropoulos D, Chemaly RF, Worth LL, et al. Infections in 100 cord blood transplanta- tions: spectrum of early and late posttransplant infections in adult and pediatric patients 1996-2005. Medicine (Baltimore). 2007;86(6):324-33.

16. van Burik JA, Carter SL, Freifeld AG, High KP, Godder KT, Papanicolaou GA, et al. Higher risk of cytomegalovirus and aspergillus infections in recipients of $\mathrm{T}$ cell-depleted unrelated bone marrow: analysis of infectious complications in patients treated with $\mathrm{T}$ cell depletion versus immunosuppressive therapy to prevent graft-versus-host disease. Biol Blood Marrow Transplant. 2007;13(12):1487-98.

17. Marty FM, Bryar J, Browne SK, Schwarzberg T, Ho VT, Bassett IV, et al. Sirolimus-based graft-versus-host disease prophylaxis protects against cytomegalovirus reactivation after allogeneic hematopoietic stem cell transplantation: a cohort analysis. Blood. 2007;110(2):490-500.

18. Demopoulos L, Polinsky M, Steele G, Mines D, Blum M, Caulfield M, et al. Reduced risk of cytomegalovirus infection in solid organ transplant recipients treated with sirolimus: a pooled analysis of clinical trials. Transplant Proc. 2008;40(5):1407-10.

19. Wingard JR, Hsu J, Hiemenz JW. Hematopoietic stem cell transplantation: an overview of infection risks and epidemiology. Infect Dis Clin N Am. 2010;24(2):257-72.

20. Bjorklund A, Aschan J, Labopin M, Remberger M, Ringden O, Winiarski J, Ljungman P. Risk factors for fatal infectious complications developing late after allogeneic stem cell transplantation. Bone Marrow Transplant. 2007;40(11):1055-62.

21. Yamasaki S, Heike Y, Mori S, Fukuda T, Maruyama D, Kato $\mathrm{R}$, et al. Infectious complications in chronic graft-versus-host disease: a retrospective study of 145 recipients of allogeneic hematopoietic stem cell transplantation with reduced- and conventional-intensity conditioning regimens. Transpl Infect Dis. 2008;10(4):252-9.

22. Fuji S, Kapp M, Einsele H. Challenges to preventing infectious complications, decreasing re-hospitalizations, and reducing cost burden in long-term survivors after allogeneic hematopoietic stem cell transplantation. Semin Hematol. 2012;49(1):10-4.

23. Guidelines for preventing opportunistic infections among hematopoietic stem cell transplant recipients. MMWR Recomm Rep. 2000;49(RR-10):1-125, CE1-7.

24. Dykewicz CA. Summary of the guidelines for preventing opportunistic infections among hematopoietic stem cell transplant recipients. Clin Infect Dis. 2001;33(2):139-44.

25. Marena C, Zecca M, Carenini ML, Bruschi A, Bassi ML, Olivieri $\mathrm{P}$, et al. Incidence of, and risk factors for, nosocomial infections among hematopoietic stem cell transplantation recipients, with impact on procedure-related mortality. Infect Control Hosp Epidemiol. 2001;22(8):510-7.

26. Gluckman E, Lotsberg J, Devergie A, Zhao XM, Melo R, Gomez-Morales $M$, et al. Prophylaxis of herpes infections after bone-marrow transplantation by oral acyclovir. Lancet. 1983;2(8352):706-8.

27. Wade JC, Newton B, Flournoy N, Meyers JD. Oral acyclovir for prevention of herpes simplex virus reactivation after marrow transplantation. Ann Intern Med. 1984;100(6):823-8.

28. Wingard JR, Merz WG, Rinaldi MG, Johnson TR, Karp JE, Saral R. Increase in Candida krusei infection among patients with bone marrow transplantation and neutropenia treated prophylactically with fluconazole. N Engl J Med. 1991;325(18):1274-7.

29. Persons DA, Laughlin M, Tanner D, Perfect J, Gockerman JP, Hathorn JW. Fluconazole and Candida krusei fungemia. N Engl J Med. 1991;325(18):1315.

30. Wingard JR, Merz WG, Rinaldi MG, Miller CB, Karp JE, Saral R. Association of Torulopsis glabrata infections with fluconazole prophylaxis in neutropenic bone marrow transplant patients. Antimicrob Agents Chemother. 1993;37(9):1847-9. 
31. Siwek GT, Dodgson KJ, de Magalhaes-Silverman M, Bartelt LA, Kilborn SB, Hoth PL, et al. Invasive zygomycosis in hematopoietic stem cell transplant recipients receiving voriconazole prophylaxis. Clin Infect Dis. 2004;39(4):584-7.

32. Kontoyiannis DP, Lionakis MS, Lewis RE, Chamilos G, Healy M, Perego C. Zygomycosis in a tertiary-care cancer center in the era of Aspergillus-active antifungal therapy: a case-control observational study of 27 recent cases. J Infect Dis. 2005;191(8):1350-60.

33. Lionakis MS, Kontoyiannis DP. Sinus zygomycosis in a patient receiving voriconazole prophylaxis. Br J Haematol. 2005;129(1):2.

34. van Well GT, van Groeningen I, Debets-Ossenkopp YJ, van Furth AM, Zwaan CM. Zygomycete infection following voriconazole prophylaxis. Lancet Infect Dis. 2005;5(9):594.

35. Collin BA, Leather HL, Wingard JR, Ramphal R. Evolution, incidence, and susceptibility of bacterial bloodstream isolates from 519 bone marrow transplant patients. Clin Infect Dis. 2001;33(7):947-53.

36. Ochs L, Shu XO, Miller J, Enright H, Wagner J, Filipovich A. Late infections after allogeneic bone marrow transplantations: comparison of incidence in related and unrelated donor transplant recipients. Blood. 1995;86(10):3979-86.

37. Roy V, Weisdorf D. Mycobacterial infections following bone marrow transplantation: a 20 year retrospective review. Bone Marrow Transplant. 1997;19(5):467-70.

38. Almyroudis NG, Fuller A, Jakubowski A, Sepkowitz K, Jaffe D, Small TN, et al. Pre- and post-engraftment bloodstream infection rates and associated mortality in allogeneic hematopoietic stem cell transplant recipients. Transpl Infect Dis. 2005;7(1):11-7.

39. Avery R, Kalaycio M, Pohlman B, Sobecks R, Kuczkowski E, Andresen S, et al. Early vancomycin-resistant enterococcus (VRE) bacteremia after allogeneic bone marrow transplantation is associated with a rapidly deteriorating clinical course. Bone Marrow Transplant. 2005;35(5):497-9.

40. Mikulska M, Del Bono V, Raiola AM, Bruno B, Gualandi F, Occhini D, et al. Blood stream infections in allogeneic hematopoietic stem cell transplant recipients: reemergence of Gram-negative rods and increasing antibiotic resistance. Biol Blood Marrow Transplant. 2009;15(1):47-53.

41. Trecarichi EM, Tumbarello M, Caira M, Candoni A, Cattaneo C, Pastore D, et al. Multidrug resistant Pseudomonas aeruginosa bloodstream infection in adult patients with hematologic malignancies. Haematologica. 2011;96(1):e1-3. author reply e4

42. Mikulska M, Del Bono V, Bruzzi P, Raiola AM, Gualandi F, Van Lint MT, et al. Mortality after bloodstream infections in allogeneic haematopoietic stem cell transplant (HSCT) recipients. Infection. 2012;40(3):271-8.

43. Garnica M, Maiolino A, Nucci M. Factors associated with bacteremia due to multidrug-resistant Gram-negative bacilli in hematopoietic stem cell transplant recipients. Braz J Med Biol Res. 2009;42(3):289-93.

44. Arango JI, Restrepo A, Schneider DL, Callander NS, OchoaBayona JL, Restrepo MI, et al. Incidence of Clostridium difficileassociated diarrhea before and after autologous peripheral blood stem cell transplantation for lymphoma and multiple myeloma. Bone Marrow Transplant. 2006;37(5):517-21.

45. Bobak D, Arfons LM, Creger RJ, Lazarus HM. Clostridium difficile-associated disease in human stem cell transplant recipients: coming epidemic or false alarm? Bone Marrow Transplant. 2008;42(11):705-13.

46. Alonso CD, Treadway SB, Hanna DB, Huff CA, Neofytos D, Carroll KC, Marr KA. Epidemiology and outcomes of Clostridium difficile infections in hematopoietic stem cell transplant recipients. Clin Infect Dis. 2012;54(8):1053-63.

47. Anand A, Glatt AE. Clostridium difficile infection associated with antineoplastic chemotherapy: a review. Clin Infect Dis. 1993;17(1):109-13.
48. Loo VG, Poirier L, Miller MA, Oughton M, Libman MD, Michaud $\mathrm{S}$, et al. A predominantly clonal multi-institutional outbreak of Clostridium difficile-associated diarrhea with high morbidity and mortality. N Engl J Med. 2005;353(23):2442-9.

49. Biller P, Shank B, Lind L, Brennan M, Tkatch L, Killgore G, et al. Moxifloxacin therapy as a risk factor for Clostridium difficile-associated disease during an outbreak: attempts to control a new epidemic strain. Infect Control Hosp Epidemiol. 2007;28(2):198-201.

50. Goorhuis A, Van der Kooi T, Vaessen N, Dekker FW, Van den Berg R, Harmanus C, et al. Spread and epidemiology of Clostridium difficile polymerase chain reaction ribotype 027/toxinotype III in The Netherlands. Clin Infect Dis. 2007;45(6):695-703.

51. Tomblyn M, Chiller T, Einsele H, Gress R, Sepkowitz K, Storek $\mathrm{J}$, Center for International Blood and Marrow Research, National Marrow Donor program, European Blood and MarrowTransplant Group, American Society of Blood and Marrow Transplantation, Canadian Blood and Marrow Transplant Group, Infectious Diseases Society of America, Society for Healthcare Epidemiology of America, Association of Medical Microbiology and Infectious Disease Canada, Centers for Disease Control and Prevention, et al. Guidelines for preventing infectious complications among hematopoietic cell transplantation recipients: a global perspective. Biol Blood Marrow Transplant. 2009;15(10):1143-238.

52. Gafter-Gvili A, Fraser A, Paul M, Leibovici L. Meta-analysis: antibiotic prophylaxis reduces mortality in neutropenic patients. Ann Intern Med. 2005;142(12 Pt 1):979-95.

53. van de Wetering MD, de Witte MA, Kremer LC, Offringa M, Scholten RJ, Caron HN. Efficacy of oral prophylactic antibiotics in neutropenic afebrile oncology patients: a systematic review of randomised controlled trials. Eur J Cancer. 2005;41(10):1372-82.

54. Cruciani M, Rampazzo R, Malena M, Lazzarini L, Todeschini G, Messori A, Concia E. Prophylaxis with fluoroquinolones for bacterial infections in neutropenic patients: a meta-analysis. Clin Infect Dis. 1996;23(4):795-805.

55. Bow EJ. Fluoroquinolones, antimicrobial resistance and neutropenic cancer patients. Curr Opin Infect Dis. 2011;24(6):545-53.

56. Chang J, Powles R, Mehta J, Paton N, Treleaven J, Jameson B. Listeriosis in bone marrow transplant recipients: incidence, clinical features, and treatment. Clin Infect Dis. 1995;21(5):1289-90.

57. Harrington RD, Woolfrey AE, Bowden R, McDowell MG, Hackman RC. Legionellosis in a bone marrow transplant center. Bone Marrow Transplant. 1996;18(2):361-8.

58. Storek J, Witherspoon RP, Webb D, Storb R. Lack of B cells precursors in marrow transplant recipients with chronic graft-versushost disease. Am J Hematol. 1996;52(2):82-9.

59. Kalhs P, Panzer S, Kletter K, Minar E, Stain-Kos M, Walter R, et al. Functional asplenia after bone marrow transplantation. A late complication related to extensive chronic graft-versus-host disease. Ann Intern Med. 1988;109(6):461-4.

60. Youssef S, Rodriguez G, Rolston KV, Champlin RE, Raad II, Safdar A. Streptococcus pneumoniae infections in 47 hematopoietic stem cell transplantation recipients: clinical characteristics of infections and vaccine-breakthrough infections, 1989-2005. Medicine (Baltimore). 2007;86(2):69-77.

61. Engelhard D, Cordonnier C, Shaw PJ, Parkalli T, Guenther C, Martino R, Infectious Disease Working Party of the European Bone Marrow Transplantation (IDWP-EBMT), et al. Early and late invasive pneumococcal infection following stem cell transplantation: a European Bone Marrow Transplantation survey. Br J Haematol. 2002;117(2):444-50.

62. Cordonnier C, Martino R, Trabasso P, Held TK, Akan H, Ward MS, European Blood and Marrow Transplant Group Infectious Diseases Working Party, et al. Mycobacterial infection: a difficult and late diagnosis in stem cell transplant recipients. Clin Infect Dis. 2004;38(9):1229-36. 
63. Unal E, Yen C, Saiman L, George D, Della-Latta P, van de Ven C, et al. A low incidence of nontuberculous mycobacterial infections in pediatric hematopoietic stem cell transplantation recipients. Biol Blood Marrow Transplant. 2006;12(11):1188-97.

64. Doucette K, Fishman JA. Nontuberculous mycobacterial infection in hematopoietic stem cell and solid organ transplant recipients. Clin Infect Dis. 2004;38(10):1428-39.

65. Au WY, Cheng VC, Ho PL, Yuen KY, Hung I, Ma SY, et al. Nontuberculous mycobacterial infections in Chinese hematopoietic stem cell transplantation recipients. Bone Marrow Transplant. 2003;32(7):709-14.

66. Gaviria JM, Garcia PJ, Garrido SM, Corey L, Boeckh M. Nontuberculous mycobacterial infections in hematopoietic stem cell transplant recipients: characteristics of respiratory and catheter-related infections. Biol Blood Marrow Transplant. 2000;6(4):361-9.

67. Russo RL, Dulley FL, Suganuma L, França IL, Yasuda MA, Costa SF. Tuberculosis in hematopoietic stem cell transplant patients: case report and review of the literature. Int J Infect Dis. 2010;14(Suppl 3):e187-91.

68. Navari RM, Sullivan KM, Springmeyer SC, Siegel MS, Meyers JD, Buckner CD, et al. Mycobacterial infections in marrow transplant patients. Transplantation. 1983;36(5):509-13.

69. Kurzrock R, Zander A, Vellekoop L, Kanojia M, Luna M, Dicke K. Mycobacterial pulmonary infections after allogeneic bone marrow transplantation. Am J Med. 1984;77(1):35-40.

70. Wang JY, Chang YL, Lee LN, Chen JH, Tang JL, Yang PC, Lee YC. Diffuse pulmonary infiltrates after bone marrow transplantation: the role of open lung biopsy. Ann Thorac Surg. 2004;78(1):267-72.

71. Daly AS, McGeer A, Lipton JH. Systemic nocardiosis following allogeneic bone marrow transplantation. Transpl Infect Dis. 2003;5(1):16-20.

72. Pao M, Papadopoulos EB, Chou J, Glenn H, Castro-Malaspina H, Jakubowski AA, et al. Response to pneumococcal (PNCRM7) and haemophilus influenzae conjugate vaccines (HIB) in pediatric and adult recipients of an allogeneic hematopoietic cell transplantation (alloHCT). Biol Blood Marrow Transplant. 2008;14(9):1022-30.

73. Toscano CM, Bell M, Zukerman C, Shelton W, Novicki TJ, Nichols WG, et al. Gram-negative bloodstream infections in hematopoietic stem cell transplant patients: the roles of needleless device use, bathing practices, and catheter care. Am J Infect Control. 2009;37(4):327-34.

74. Benjamin D, Miller WC, Bayliff S, Martel L, Alexander K, Martin PL. Infections diagnosed in the first year after pediatric stem cell transplantation. Pediatr Infect Dis J. 2002;21(3):227-34.

75. Bate SL, Dollard SC, Cannon MJ. Cytomegalovirus seroprevalence in the United States: the national health and nutrition examination surveys, 1988-2004. Clin Infect Dis. 2010;50(11):1439-47.

76. Urwijitaroon Y, Teawpatanataworn S, Kitjareontarm A. Prevalence of cytomegalovirus antibody in Thai-northeastern blood donors. Southeast Asian J Trop Med Public Health. 1993;24(Suppl 1):180-2.

77. Souza MA, Passos AM, Treitinger A, Spada C. Seroprevalence of cytomegalovirus antibodies in blood donors in southern, Brazil. Rev Soc Bras Med Trop. 2010;43(4):359-61.

78. Miller W, Flynn P, McCullough J, Balfour HH Jr, Goldman A, Haake R, et al. Cytomegalovirus infection after bone marrow transplantation: an association with acute graft-v-host disease. Blood. 1986;67(4):1162-7.

79. Montesinos P, Sanz J, Cantero S, Lorenzo I, Martín G, Saavedra $\mathrm{S}$, et al. Incidence, risk factors, and outcome of cytomegalovirus infection and disease in patients receiving prophylaxis with oral valganciclovir or intravenous ganciclovir after umbili- cal cord blood transplantation. Biol Blood Marrow Transplant. 2009; 15(6):730-40.

80. Goodrich JM, Bowden RA, Fisher L, Keller C, Schoch G, Meyers JD. Ganciclovir prophylaxis to prevent cytomegalovirus disease after allogeneic marrow transplant. Ann Intern Med. 1993;118(3):173-8.

81. Winston DJ, Ho WG, Bartoni K, Du Mond C, Ebeling DF, Buhles WC, Champlin RE. Ganciclovir prophylaxis of cytomegalovirus infection and disease in allogeneic bone marrow transplant recipients. Results of a placebo-controlled, double-blind trial. Ann Intern Med. 1993;118(3):179-84.

82. Ayala E, Greene J, Sandin R, Perkins J, Field T, Tate C, et al. Valganciclovir is safe and effective as pre-emptive therapy for CMV infection in allogeneic hematopoietic stem cell transplantation. Bone Marrow Transplant. 2006;37(9):851-6.

83. Boeckh M, Leisenring W, Riddell SR, Bowden RA, Huang ML, Myerson D, et al. Late cytomegalovirus disease and mortality in recipients of allogeneic hematopoietic stem cell transplants: importance of viral load and T-cell immunity. Blood. 2003;101(2):407-14.

84. Nichols WG, Corey L, Gooley T, Davis C, Boeckh M. High risk of death due to bacterial and fungal infection among cytomegalovirus (CMV)-seronegative recipients of stem cell transplants from seropositive donors: evidence for indirect effects of primary CMV infection. J Infect Dis. 2002;185(3):273-82.

85. Boeckh M, Nichols WG, Papanicolaou G, Rubin R, Wingard JR, Zaia J. Cytomegalovirus in hematopoietic stem cell transplant recipients: current status, known challenges, and future strategies. Biol Blood Marrow Transplant. 2003;9(9):543-58.

86. Boeckh M, Ljungman P. How we treat cytomegalovirus in hematopoietic cell transplant recipients. Blood. 2009;113(23):5711-9.

87. Alexander BT, Hladnik LM, Augustin KM, Casabar E, McKinnon PS, Reichley RM, et al. Use of cytomegalovirus intravenous immune globulin for the adjunctive treatment of cytomegalovirus in hematopoietic stem cell transplant recipients. Pharmacotherapy. 2010;30(6):554-61.

88. Mui TS, Kapp M, Einsele H, Grigoleit GU. T-cell therapy for cytomegalovirus infection. Curr Opin Organ Transplant. 2010;15(6):744-50.

89. Bernstein DI. Vaccines for cytomegalovirus. Infect Disord Drug Targets. 2011;11(5):514-25.

90. Kharfan-Dabaja MA, Boeckh M, Wilck MB, Langston AA, Chu $\mathrm{AH}$, Wloch MK, et al. A novel therapeutic cytomegalovirus DNA vaccine in allogeneic haemopoietic stem-cell transplantation: a randomised, double-blind, placebo-controlled, phase 2 trial. Lancet Infect Dis. 2012;12(4):290-9.

91. Jagadeesh D, Woda BA, Draper J, Evens AM. Post transplant lymphoproliferative disorders: risk, classification, and therapeutic recommendations. Curr Treat Options in Oncol. 2012;13(1):122-36.

92. Landgren O, Gilbert ES, Rizzo JD, Socié G, Banks PM, Sobocinski KA, et al. Risk factors for lymphoproliferative disorders after allogeneic hematopoietic cell transplantation. Blood. 2009; 113(20):4992-5001.

93. Ocheni S, Kroeger N, Zabelina T, Sobottka I, Ayuk F, Wolschke $\mathrm{C}$, et al. EBV reactivation and post transplant lymphoproliferative disorders following allogeneic SCT. Bone Marrow Transplant. 2008;42(3):181-6.

94. Blaes AH, Cao Q, Wagner JE, Young JA, Weisdorf DJ, Brunstein CG. Monitoring and preemptive rituximab therapy for Epstein-Barr virus reactivation after antithymocyte globulin containing nonmyeloablative conditioning for umbilical cord blood transplantation. Biol Blood Marrow Transplant. 2010;16(2):287-91.

95. Styczynski J, Einsele H, Gil L, Ljungman P. Outcome of treatment of Epstein-Barr virus-related post-transplant lymphop- 
roliferative disorder in hematopoietic stem cell recipients: a comprehensive review of reported cases. Transpl Infect Dis. 2009;11(5):383-92.

96. Xu F, Sternberg MR, Kottiri BJ, McQuillan GM, Lee FK, Nahmias AJ, et al. Trends in herpes simplex virus type 1 and type 2 seroprevalence in the United States. JAMA. 2006;296(8):964-73.

97. Meyers JD, Flournoy N, Thomas ED. Infection with herpes simplex virus and cell-mediated immunity after marrow transplant. J Infect Dis. 1980;142(3):338-46.

98. Wade JC, Day LM, Crowley JJ, Meyers JD. Recurrent infection with herpes simplex virus after marrow transplantation: role of the specific immune response and acyclovir treatment. J Infect Dis. 1984;149(5):750-6.

99. Gasparetto EL, Escuissato DL, Inoue C, Marchiori E, Müller NL. Herpes simplex virus type 2 pneumonia after bone marrow transplantation: high-resolution CT findings in 3 patients. $J$ Thorac Imaging. 2005;20(2):71-3.

100. Ramsey PG, Fife KH, Hackman RC, Meyers JD, Corey L. Herpes simplex virus pneumonia: clinical, virologic, and pathologic features in 20 patients. Ann Intern Med. 1982;97(6):813-20.

101. Kaufman B, Gandhi SA, Louie E, Rizzi R, Illei P. Herpes simplex virus hepatitis: case report and review. Clin Infect Dis. 1997;24(3):334-8.

102. Momméja-Marin H, Lafaurie M, Scieux C, Galicier L, Oksenhendler E, Molina JM. Herpes simplex virus type 2 as a cause of severe meningitis in immunocompromised adults. Clin Infect Dis. 2003;37(11):1527-33.

103. Robinson MJ, Newton C. Bilateral herpes simplex keratitis in a patient with graft-vs-host disease. Am J Ophthalmol 1991;112(4):468-9.

104. Ballen KK, Donadio D, Bouloux C, McCarthy P, Weinstein H, Antin JH. Herpes simplex virus and neutropenia following bone marrow transplantation. Transplantation. 1992;54(3):553-5.

105. Rogers JE, Cumpston A, Newton M, Craig M. Onset and complications of varicella zoster reactivation in the autologous hematopoietic cell transplant population. Transpl Infect Dis. 2011;13(5):480-4

106. Oshima K, Takahashi T, Mori T, Matsuyama T, Usuki K, AsanoMori Y, et al. One-year low-dose valacyclovir as prophylaxis for varicella zoster virus disease after allogeneic hematopoietic stem cell transplantation. A prospective study of the Japan Hematology and Oncology Clinical Study Group. Transpl Infect Dis. 2010;12(5):421-7.

107. Steer CB, Szer J, Sasadeusz J, Matthews JP, Beresford JA, Grigg A. Varicella-zoster infection after allogeneic bone marrow transplantation: incidence, risk factors and prevention with low-dose aciclovir and ganciclovir. Bone Marrow Transplant. 2000;25(6):657-64.

108. Kim DH, Messner H, Minden M, Gupta V, Kuruvilla J, Wright J, Lipton J. Factors influencing varicella zoster virus infection after allogeneic peripheral blood stem cell transplantation: low-dose acyclovir prophylaxis and pre-transplant diagnosis of lymphoproliferative disorders. Transpl Infect Dis. 2008;10(2):90-8.

109. Zerr DM, Boeckh M, Delaney C, Martin PJ, Xie H, Adler $\mathrm{AL}$, et al. HHV-6 reactivation and associated sequelae after hematopoietic cell transplant. Biol Blood Marrow Transplant. 2012;18(11):1700-8.

110. Zerr DM, Corey L, Kim HW, Huang ML, Nguy L, Boeckh M. Clinical outcomes of human herpesvirus 6 reactivation after hematopoietic stem cell transplantation. Clin Infect Dis 2005;40(7):932-40.

111. Trifilio SM, Bennett CL, Yarnold PR, McKoy JM, Parada J, Mehta $\mathrm{J}$, et al. Breakthrough zygomycosis after voriconazole administration among patients with hematologic malignancies who receive hematopoietic stem-cell transplants or intensive chemotherapy. Bone Marrow Transplant. 2007;39(7):425-9.
112. Hill JA, Koo S, Guzman Suarez BB, Ho VT, Cutler C, Koreth J, et al. Cord-blood hematopoietic stem cell transplant confers an increased risk for human herpesvirus-6-associated acute limbic encephalitis: a cohort analysis. Biol Blood Marrow Transplant. 2012;18(11):1638-48.

113. Yamane A, Mori T, Suzuki S, Mihara A, Yamazaki R, Aisa Y, et al. Risk factors for developing human herpesvirus 6 (HHV-6) reactivation after allogeneic hematopoietic stem cell transplantation and its association with central nervous system disorders. Biol Blood Marrow Transplant. 2007;13(1):100-6.

114. Olli-Lähdesmäki T, Haataja L, Parkkola R, Waris M, Bleyzac N, Ruuskanen O. High-dose ganciclovir in HHV-6 encephalitis of an immunocompetent child. Pediatr Neurol. 2010;43(1):53-6.

115. Yoshikawa T, Yoshida J, Hamaguchi M, Kubota T, Akimoto S, Ihira M, et al. Human herpesvirus 7-associated meningitis and optic neuritis in a patient after allogeneic stem cell transplantation. J Med Virol. 2003;70(3):440-3.

116. de Medeiros BC, Rezuke WN, Ricci A Jr, Tsongalis G, Shen PU, Bona RD, et al. Kaposi's sarcoma following allogeneic hematopoietic stem cell transplantation for chronic myelogenous leukemia. Acta Haematol. 2000;104(2-3):115-8.

117. van Tol MJD, Kroes ACM, Schinkel J, Dinkelaar W, Claas ECJ, et al. Adenovirus infection in paediatric stem cell transplant recipients: increased risk in young children with a delayed immune recovery. Bone Marrow Transplant. 2005;36(1):39-50.

118. Taniguchi K, Yoshihara S, Tamaki H, Fujimoto T, Ikegame K, Kaida $\mathrm{K}$, et al. Incidence and treatment strategy for disseminated adenovirus disease after haploidentical stem cell transplantation. Ann Hematol. 2012;91(8):1305-12.

119. Nichols WG, Guthrie KA, Corey L, Boeckh M. Influenza infections after hematopoietic stem cell transplantation: risk factors, mortality, and the effect of antiviral therapy. Clin Infect Dis. 2004;39(9):1300-6.

120. Nichols WG, Corey L, Gooley T, Davis C, Boeckh M. Parainfluenza virus infections after hematopoietic stem cell transplantation: risk factors, response to antiviral therapy, and effect on transplant outcome. Blood. 2001;98(3):573-8.

121. Avetisyan G, Mattsson J, Sparrelid E, Ljungman P. Respiratory syncytial virus infection in recipients of allogeneic stem-cell transplantation: a retrospective study of the incidence, clinical features, and outcome. Transplantation. 2009;88(10):1222-6.

122. Debur MC, Vidal LR, Stroparo E, Nogueira MB, Almeida SM, Takahashi GA, et al. Human metapneumovirus infection in hematopoietic stem cell transplant recipients. Transpl Infect Dis. 2010;12(2):173-9.

123. Milano F, Campbell AP, Guthrie KA, Kuypers J, Englund JA, et al. Human rhinovirus and coronavirus detection among allogeneic hematopoietic stem cell transplantation recipients. Blood. 2010;115(10):2088-94.

124. Weigt SS, Gregson AL, Deng JC, Lynch JP 3rd, Belperio JA. Respiratory viral infections in hematopoietic stem cell and solid organ transplant recipients. Semin Respir Crit Care Med. 2011;32(4):471-93.

125. Chemaly RF, Ghosh S, Bodey GP, Rohatgi N, Safdar A, Keating $\mathrm{MJ}$, et al. Respiratory viral infections in adults with hematologic malignancies and human stem cell transplantation recipients: a retrospective study at a major cancer center. Medicine (Baltimore). 2006;85(5):278-87.

126. Hammond SP, Borchelt AM, Ukomadu C, Ho VT, Baden LR, Marty FM. Hepatitis B virus reactivation following allogeneic hematopoietic stem cell transplantation. Biol Blood Marrow Transplant. 2009;15(9):1049-59.

127. Giaccone L, Festuccia M, Marengo A, Resta I, Sorasio R, Pittaluga $\mathrm{F}$, et al. Hepatitis B virus reactivation and efficacy of prophylaxis with lamivudine in patients undergoing allogeneic stem cell transplantation. Biol Blood Marrow Transplant. 2010;16(6):809-17. 
128. Sanchez-Pinto LN, Laskin BL, Jodele S, Hummel TR, Yin HJ, Goebel J. BK virus nephropathy in a pediatric autologous stemcell transplant recipient. Pediatr Blood Cancer. 2011;56(3):495-7.

129. Lekakis LJ, Macrinici V, Baraboutis IG, Mitchell B, Howard DS. BK virus nephropathy after allogeneic stem cell transplantation: a case report and literature review. Am J Hematol. 2009;84(4):243-6.

130. O'Donnell PH, Swanson K, Josephson MA, Artz AS, Parsad $\mathrm{SD}$, Ramaprasad C, et al. BK virus infection is associated with hematuria and renal impairment in recipients of allogeneic hematopoietic stem cell transplants. Biol Blood Marrow Transplant. 2009;15(9):1038-1048 e1.

131. Dropulic LK, Jones RJ. Polyomavirus BK infection in blood and marrow transplant recipients. Bone Marrow Transplant. 2008;41(1):11-8.

132. Steurer M, Clausen J, Gotwald T, Gunsilius E, Stockhammer G, Gastl G, Nachbaur D. Progressive multifocal leukoencephalopathy after allogeneic stem cell transplantation and posttransplantation rituximab. Transplantation. 2003;76(2):435-6.

133. Goodrich JM, Reed EC, Mori M, Fisher LD, Skerrett S, Dandliker PS, et al. Clinical features and analysis of risk factors for invasive candidal infection after marrow transplantation. J Infect Dis. 1991;164(4):731-40.

134. Marr KA, Seidel K, White TC, Bowden RA. Candidemia in allogeneic blood and marrow transplant recipients: evolution of risk factors after the adoption of prophylactic fluconazole. J Infect Dis. 2000;181(1):309-16.

135. Goodman JL, Winston DJ, Greenfield RA, Chandrasekar PH, Fox B, Kaizer H, et al. A controlled trial of fluconazole to prevent fungal infections in patients undergoing bone marrow transplantation. N Engl J Med. 1992;326(13):845-51.

136. Slavin MA, Osborne B, Adams R, Levenstein MJ, Schoch HG, Feldman AR, et al. Efficacy and safety of fluconazole prophylaxis for fungal infections after marrow transplantation - a prospective, randomized, double-blind study. J Infect Dis. 1995;171(6): 1545-52.

137. Marr KA, Seidel K, Slavin MA, Bowden RA, Schoch HG, Flowers ME, et al. Prolonged fluconazole prophylaxis is associated with persistent protection against candidiasis-related death in allogeneic marrow transplant recipients: long-term follow-up of a randomized, placebo-controlled trial. Blood. 2000;96(6):2055-61.

138. Neofytos D, Horn D, Anaissie E, Steinbach W, Olyaei A, Fishman $\mathrm{J}$, et al. Epidemiology and outcome of invasive fungal infection in adult hematopoietic stem cell transplant recipients: analysis of Multicenter Prospective Antifungal Therapy (PATH) Alliance registry. Clin Infect Dis. 2009;48(3):265-73.

139. Horn DL, Neofytos D, Anaissie EJ, Fishman JA, Steinbach WJ, Olyaei AJ, et al. Epidemiology and outcomes of candidemia in 2019 patients: data from the prospective antifungal therapy alliance registry. Clin Infect Dis. 2009;48(12):1695-703.

140. Rossetti F, Brawner DL, Bowden R, Meyer WG, Schoch HG, Fisher L, et al. Fungal liver infection in marrow transplant recipients: prevalence at autopsy, predisposing factors, and clinical features. Clin Infect Dis. 1995;20(4):801-11.

141. Hart PD, Russell E Jr, Remington JS. The compromised host and infection. II. Deep fungal infection. J Infect Dis. 1969;120(2):169-91.

142. Held J, Kohlberger I, Rappold E, Busse Grawitz A, Häcker G. Comparison of (1->3)-beta-D-glucan, mannan/anti-mannan antibodies, and Cand-Tec Candida antigen as serum biomarkers for candidemia. J Clin Microbiol. 2013;51(4):1158-64.

143. Mora-Duarte J, Betts R, Rotstein C, Colombo AL, ThompsonMoya L, Smietana J, Caspofungin Invasive Candidiasis Study Group, et al. Comparison of caspofungin and amphotericin B for invasive candidiasis. N Engl J Med. 2002;347(25):2020-9.
144. Kuse ER, Chetchotisakd P, da Cunha CA, Ruhnke M, Barrios C, Raghunadharao D, Micafungin Invasive Candidiasis Working Group, et al. Micafungin versus liposomal amphotericin B for candidaemia and invasive candidosis: a phase III randomised double-blind trial. Lancet. 2007;369(9572):1519-27.

145. Lockhart SR, Wagner D, Iqbal N, Pappas PG, Andes DR, Kauffman CA, et al. Comparison of in vitro susceptibility characteristics of Candida species from cases of invasive candidiasis in solid organ and stem cell transplant recipients: TransplantAssociated Infections Surveillance Network (TRANSNET), 2001 to 2006. J Clin Microbiol. 2011;49(7):2404-10.

146. Pappas PG, Kauffman CA, Andes D, Benjamin DK Jr, Calandra TF, Edwards JE Jr, Infectious Diseases Society of America, et al. Clinical practice guidelines for the management of candidiasis: 2009 update by the Infectious Diseases Society of America. Clin Infect Dis. 2009;48(5):503-35.

147. Wald A, Leisenring W, van Burik JA, Bowden RA. Epidemiology of Aspergillus infections in a large cohort of patients undergoing bone marrow transplantation. J Infect Dis. 1997;175(6):1459-66.

148. Marr KA, Carter RA, Boeckh M, Martin P, Corey L. Invasive aspergillosis in allogeneic stem cell transplant recipients: changes in epidemiology and risk factors. Blood. 2002;100(13):4358-66.

149. Seo KW, Kim DH, Sohn SK, Lee NY, Chang HH, Kim SW, et al. Protective role of interleukin-10 promoter gene polymorphism in the pathogenesis of invasive pulmonary aspergillosis after allogeneic stem cell transplantation. Bone Marrow Transplant. 2005;36(12):1089-95.

150. Garcia-Vidal C, Upton A, Kirby KA, Marr KA. Epidemiology of invasive mold infections in allogeneic stem cell transplant recipients: biological risk factors for infection according to time after transplantation. Clin Infect Dis. 2008;47(8):1041-50.

151. Bochud PY, Chien JW, Marr KA, Leisenring WM, Upton A, Janer M, et al. Toll-like receptor 4 polymorphisms and aspergillosis in stem-cell transplantation. $\mathrm{N}$ Engl J Med. 2008;359(17):1766-77.

152. Kesh S, Mensah NY, Peterlongo P, Jaffe D, Hsu K, VAN DEN Brink M, et al. TLR1 and TLR6 polymorphisms are associated with susceptibility to invasive aspergillosis after allogeneic stem cell transplantation. Ann N Y Acad Sci. 2005;1062:95-103.

153. Zaas AK, Liao G, Chien JW, Weinberg C, Shore D, Giles SS, et al. Plasminogen alleles influence susceptibility to invasive aspergillosis. PLoS Genet. 2008;4(6):e1000101.

154. Mezger M, Steffens M, Beyer M, Manger C, Eberle J, et al. Polymorphisms in the chemokine (C-X-C motif) ligand 10 are associated with invasive aspergillosis after allogeneic stem-cell transplantation and influence CXCL10 expression in monocytederived dendritic cells. Blood. 2008;111(2):534-6.

155. Sainz J, Pérez E, Gómez-Lopera S, Jurado M. IL1 gene cluster polymorphisms and its haplotypes may predict the risk to develop invasive pulmonary aspergillosis and modulate C-reactive protein level. J Clin Immunol. 2008;28(5):473-85.

156. Martino R, Caballero MD, Canals C, San Miguel J, Sierra J, Rovira M, alloPBSCT and Infectious/nonifectious Complications Subcommittees of the Grupo Español de Transplante Hematopoyético (GETH), et al. Reduced-intensity conditioning reduces the risk of severe infections after allogeneic peripheral blood stem cell transplantation. Bone Marrow Transplant. 2001;28(4):341-7.

157. Fukuda T, Boeckh M, Carter RA, Sandmaier BM, Maris MB, Maloney DG, et al. Risks and outcomes of invasive fungal infections in recipients of allogeneic hematopoietic stem cell transplants after nonmyeloablative conditioning. Blood. 2003;102(3):827-33.

158. Labbé AC, Su SH, Laverdière M, Pépin J, Patiño C, Cohen S, et al. High incidence of invasive aspergillosis associated with intestinal graft-versus-host disease following nonmyeloablative transplantation. Biol Blood Marrow Transplant. 2007;13(10):1192-200. 
159. Marr KA, Carter RA, Crippa F, Wald A, Corey L. Epidemiology and outcome of mould infections in hematopoietic stem cell transplant recipients. Clin Infect Dis. 2002;34(7):909-17.

160. Kojima R, Tateishi U, Kami M, Murashige N, Nannya Y, Kusumi $\mathrm{E}$, et al. Chest computed tomography of late invasive aspergillosis after allogeneic hematopoietic stem cell transplantation. Biol Blood Marrow Transplant. 2005;11(7):506-11.

161. Marr KA, Balajee SA, McLaughlin L, Tabouret M, Bentsen C, Walsh TJ. Detection of galactomannan antigenemia by enzyme immunoassay for the diagnosis of invasive aspergillosis: variables that affect performance. J Infect Dis. 2004;190(3):641-9.

162. Boutboul F, Alberti C, Leblanc T, Sulahian A, Gluckman E, Derouin F, Ribaud P. Invasive aspergillosis in allogeneic stem cell transplant recipients: increasing antigenemia is associated with progressive disease. Clin Infect Dis. 2002;34(7):939-43.

163. Nguyen MH, Leather H, Clancy CJ, Cline C, Jantz MA, Kulkarni $\mathrm{V}$, et al. Galactomannan testing in bronchoalveolar lavage fluid facilitates the diagnosis of invasive pulmonary aspergillosis in patients with hematologic malignancies and stem cell transplant recipients. Biol Blood Marrow Transplant. 2011;17(7):1043-50.

164. Marr KA, Laverdiere M, Gugel A, Leisenring W. Antifungal therapy decreases sensitivity of the Aspergillus galactomannan enzyme immunoassay. Clin Infect Dis. 2005;40(12):1762-9.

165. Machetti M, Furfaro E, Viscoli C. Galactomannan in piperacillintazobactam: how much and to what extent? Antimicrob Agents Chemother. 2005;49(9):3984-5.

166. Hage CA, Reynolds JM, Durkin M, Wheat J, Knox KS. Plasmalyte as a cause of false-positive results for Aspergillus galactomannan in bronchoalveolar lavage fluid. J Clin Microbiol. 2007;45(2):676-7.

167. Herbrecht R, Denning DW, Patterson TF, Bennett JE, Greene RE, Oestmann JW, Invasive Fungal Infections Group of the European Organisation for Research and Treatment of Cancer and the Global Aspergillus Study Group, et al. Voriconazole versus amphotericin $\mathrm{B}$ for primary therapy of invasive aspergillosis. N Engl J Med. 2002;347(6):408-15.

168. Walsh TJ, Anaissie EJ, Denning DW, Herbrecht R, Kontoyiannis DP, Marr KA, Infectious Diseases Society of America, et al. Treatment of aspergillosis: clinical practice guidelines of the Infectious Diseases Society of America. Clin Infect Dis. 2008;46(3):327-60.

169. Kontoyiannis DP, Hachem R, Lewis RE, Rivero GA, Torres HA, Thornby $\mathrm{J}$, et al. Efficacy and toxicity of caspofungin in combination with liposomal amphotericin B as primary or salvage treatment of invasive aspergillosis in patients with hematologic malignancies. Cancer. 2003;98(2):292-9.

170. Marr KA, Schlamm HT, Herbrecht R, Rottinghaus ST, Bow EJ, Cornely OA, et al. Combination antifungal therapy for invasive aspergillosis. Clin Infect Dis. 2004;39(6):797-802.

171. Cordonnier C, Rovira M, Maertens J, Olavarria E, Faucher C, Bilger K, Voriconazole for Secondary Prophylaxis of Invasive Fungal Infections in Patients With Allogeneic Stem Cell Transplants (VOSIFI) study group, Infectious Diseases Working Party, European Group for Blood and Marrow Transplantation, et al. Voriconazole for secondary prophylaxis of invasive fungal infections in allogeneic stem cell transplant recipients: results of the VOSIFI study. Haematologica. 2010;95(10):1762-8.

172. El-Cheikh J, Castagna L, Wang L, Esterni B, Faucher C, Fürst $\mathrm{S}$, et al. Impact of prior invasive aspergillosis on outcome in patients receiving reduced-intensity conditioning allogeneic hematopoietic stem cell transplant. Leuk Lymphoma. 2010;51(9):1705-10.

173. Gaziev D, Baronciani D, Galimberti M, Polchi P, Angelucci E, Giardini C, et al. Mucormycosis after bone marrow transplantation: report of four cases in thalassemia and review of the literature. Bone Marrow Transplant. 1996;17(3):409-14.
174. Roden MM, Zaoutis TE, Buchanan WL, Knudsen TA, Sarkisova TA, Schaufele RL, et al. Epidemiology and outcome of zygomycosis: a review of 929 reported cases. Clin Infect Dis. 2005;41(5):634-53.

175. Imhof A, Balajee SA, Fredricks DN, Englund JA, Marr KA. Breakthrough fungal infections in stem cell transplant recipients receiving voriconazole. Clin Infect Dis. 2004;39(5):743-6.

176. Nucci M, Marr KA, Queiroz-Telles F, Martins CA, Trabasso P, Costa S, et al. Fusarium infection in hematopoietic stem cell transplant recipients. Clin Infect Dis. 2004;38(9):1237-42.

177. Anaissie EJ, Kuchar RT, Rex JH, Francesconi A, Kasai M, Müller FM, et al. Fusariosis associated with pathogenic fusarium species colonization of a hospital water system: a new paradigm for the epidemiology of opportunistic mold infections. Clin Infect Dis. 2001;33(11):1871-8.

178. Boutati EI, Anaissie EJ. Fusarium, a significant emerging pathogen in patients with hematologic malignancy: ten years' experience at a cancer center and implications for management. Blood. 1997;90(3):999-1008

179. Husain S, Muñoz P, Forrest G, Alexander BD, Somani J, Brennan $\mathrm{K}$, et al. Infections due to Scedosporium apiospermum and Scedosporium prolificans in transplant recipients: clinical characteristics and impact of antifungal agent therapy on outcome. Clin Infect Dis. 2005;40(1):89-99.

180. Bhatti Z, Shaukat A, Almyroudis NG, Segal BH. Review of epidemiology, diagnosis, and treatment of invasive mould infections in allogeneic hematopoietic stem cell transplant recipients. Mycopathologia. 2006;162(1):1-15.

181. De Castro N, Neuville S, Sarfati C, Ribaud P, Derouin F, Gluckman E, et al. Occurrence of Pneumocystis jiroveci pneumonia after allogeneic stem cell transplantation: a 6-year retrospective study. Bone Marrow Transplant. 2005;36(10):879-83.

182. Torres HA, Chemaly RF, Storey R, Aguilera EA, Nogueras GM, Safdar A, et al. Influence of type of cancer and hematopoietic stem cell transplantation on clinical presentation of Pneumocystis jiroveci pneumonia in cancer patients. Eur J Clin Microbiol Infect Dis. 2006;25(6):382-8.

183. Lyytikäinen O, Ruutu T, Volin L, Lautenschlager I, Jokipii L, et al. Late onset Pneumocystis carinii pneumonia following allogeneic bone marrow transplantation. Bone Marrow Transplant. 1996;17(6):1057-9.

184. Tuan IZ, Dennison D, Weisdorf DJ. Pneumocystis carinii pneumonitis following bone marrow transplantation. Bone Marrow Transplant. 1992;10(3):267-72.

185. Mulanovich VE, Ahmed SI, Öztürk T, Khokhar FA, Kontoyiannis DP, de Lima M. Toxoplasmosis in allo-SCT patients: risk factors and outcomes at a transplantation center with a low incidence. Bone Marrow Transplant. 2011;46(2):273-7.

186. Slavin MA, Meyers JD, Remington JS, Hackman RC. Toxoplasma gondii infection in marrow transplant recipients: a 20 year experience. Bone Marrow Transplant. 1994;13(5):549-57.

187. Derouin F, Devergie A, Auber P, Gluckman E, Beauvais B, Garin YJ, Lariviere M. Toxoplasmosis in bone marrow-transplant recipients: report of seven cases and review. Clin Infect Dis. 1992;15(2):267-70

188. Cavattoni I, Ayuk F, Zander AR, Zabelina T, Bacher A, Cayroglu E, et al. Diagnosis of Toxoplasma gondii infection after allogeneic stem cell transplant can be difficult and requires intensive scrutiny. Leuk Lymphoma. 2010;51(8):1530-5.

189. Edvinsson B, Lundquist J, Ljungman P, Ringdén O, Evengård B. A prospective study of diagnosis of Toxoplasma gondii infection after bone marrow transplantation. APMIS. 2008;116(5):345-51.

190. Bautista G, Ramos A, Forés R, Regidor C, Ruiz E, de Laiglesia A, et al. Toxoplasmosis in cord blood transplantation recipients. Transpl Infect Dis. 2012;14(5):496-501. 
191. Derouin F, Pelloux H. Prevention of toxoplasmosis in transplant patients. Clin Microbiol Infect. 2008;14(12):1089-101.

192. Wirk B, Wingard JR. Strongyloides stercoralis hyperinfection in hematopoietic stem cell transplantation. Transpl Infect Dis. 2009;11(2):143-8.

193. Gupta S, Jain A, Fanning TV, Couriel DR, Jimenez CA, Eapen GA. An unusual cause of alveolar hemorrhage post hematopoietic stem cell transplantation: a case report. BMC Cancer. 2006;6:87.

194. Recommendations of the Center for International Blood and Marrow Transplant Research (CIBMTR $\left.{ }^{\circledR}\right)$, the National Marrow Donor Program (NMDP), the European Blood and Marrow Transplant Group (EBMT), the American Society of Blood and Marrow Transplantation (ASBMT), the Canadian Blood and Marrow Transplant Group (CBMTG), the Infectious Disease Society of America (IDSA), the Society for Healthcare Epidemiology of America (SHEA), the Association of
Medical Microbiology and Infectious Diseases Canada (AMMI), the Centers for Disease Control and Prevention (CDC), Tomblyn M, Chiller T, Einsele H, Gress R, Sepkowitz K, et al. Guidelines for preventing infectious complications among hematopoietic cell transplant recipients: a global perspective. Bone Marrow Transplant. 2009;44(8):453-558.

195. Ljungman P, Cordonnier C, Einsele H, Englund J, Machado CM, Center for International Blood and Marrow Transplant Research, National Marrow Donor Program, European Blood and Marrow Transplant Group, American Society of Blood and Marrow Transplantation, Canadian Blood and Marrow Transplant Group, Infectious Disease Society of America, Society for Healthcare Epidemiology of America, Association of Medical Microbiology and Infectious Diseases Canada, Centers for Disease Control and Prevention, et al. Vaccination of hematopoietic cell transplant recipients. Bone Marrow Transplant. 2009;44(8):521-6. 